Łukasz Jastrząb

(PAN Biblioteka Kórnicka)

\title{
Poznański Czerwiec 1956 r. w kulturze i historiografii
}

Poznański Czerwiec 1956 r. to wydarzenie, które na trwale odcisnęło swe piętno w historii powojennego Poznania. Strajk ekonomiczny i zamieszki zbrojne, jako jego następstwo oraz idące za wydarzeniami skutki polityczne - mniej lub bardziej trwałe dla ówczesnego systemu politycznego - znalazły swoje odbicie w szeroko rozumianej (by nie wchodzić w konteksty definicyjne) historiografii oraz kulturze.

\section{Poezja i proza}

Już 4 lipca 1956 r. Kazimiera Iłłakowiczówna ${ }^{1}$ napisała wiersz Rozstrzelano moje serce $w$ Poznaniu. Został wydrukowany po raz pierwszy w szczecińskim tygodniku "Ziemia i Morze" ${ }^{2}$ i stał się on symbolem poezji Poznańskiego Czerwca: „Chciałam o kulturze napisać naprawdę inteligentnie, lecz zaczęły kule świstać i szyby dygotać i pękać / - „Czemu zawsze rządzi inteligent, a do robotników się strzela?" Innym znanym wierszem, często cytowanym, jest utwór poświęcony Romanowi Strzałkowskiemu Śpij spokojnie mój mały

${ }^{1}$ Kazimiera Iłłakowiczówna (1892-1983).

2 "Ziemia i Morze” nr 24 z 27 października 1956 r., s. 1. Według Moniki Chudej, badaczki twórczości Kazimiery Iłłakowiczówny, w Wielkopolsce tekst utworu został opublikowany dopiero w 1981 r., w nr. 119 "Głosu Wielkopolskiego"; M. Chuda, Z adresownika poetki. Śladami listów Kazimiery Iłłakowiczówny w bibliotekach polskich, „Biblioteka” 2010, nr 14(23), s. 205.

${ }^{3}$ Roman Strzałkowski (1943-1956), jedna z 57 ofiar Poznańskiego Czerwca 1956 r., jego przypadkowa śmierć stała się źródłem legend i mitów o celowym morderstwie przez funkcjonariuszy Urzędu Bezpieczeństwa. 
chłopczyku Konrada Doberschuetza ${ }^{4}$, za napisanie którego autor został skazany w 1959 r. na trzy lata więzienia. Poezja dotycząca Poznańskiego Czerwca 1956 r. jest skromna - można doliczyć się przeszło pięćdziesięciu utworów poetyckich, bardzo rozproszonych, które ukazywały się najczęściej w prasie drugiego obiegu. Pierwszą osobą, która w szerszy sposób zajęła się omówieniem poezji dotyczącej tych wydarzeń, był Jarosław Maciejewski ${ }^{5}$. Siedem lat później Sergiusz Sterna-Wachowiak ${ }^{6}$ opublikował pogłębiony szkic o tej tematyce; chociaż napisany mało przystępnym dla czytelnika językiem, trudny $\mathrm{w}$ zrozumieniu, to pozostaje jedynym $\mathrm{w}$ historiografii syntetycznym ujęciem tematu ${ }^{7}$. Stefan Drajewski ${ }^{8}$ dokonał w 2008 r. żmudnej pracy i zebrał kilkadziesiąt wierszy dotyczących Poznańskiego Czerwca 1956 r. w jednym zbiorze ${ }^{9}$. Ten unikatowy zbiór uzupełniają biogramy 36 autorów tejże poezji. Z okazji sześćdziesiątej rocznicy Poznańskiego Czerwca poznańska Fundacja Barak Kultury zorganizowała performance, podczas którego była prezentowana poezja dotycząca niniejszych wydarzeń, m.in. tren poświęcony Romanowi Strzałkowskiemu. Wiersz napisali poeci związani z Poznaniem: Joanna Roszak, Kira Pietrek, Szczepan Kopyt i Łukasz Bukowski ${ }^{10}$.

Z historią Poznańskiego Czerwca, jego symboliką, rozliczeniem, próbowali się zmierzyć również prozaicy - w mniej lub bardziej udany sposób. Już w lipcu 1956 r. Czesław Michniak ${ }^{11}$ napisał krótką nowelę Tego dnia, opublikowaną w 1957 r. w zbiorze Opowiadania poznańskie ${ }^{12}$. Od końca 1956 r. do

${ }^{4}$ Konrad Doberschuetz (1921-2000) - dziennikarz.

${ }^{5}$ Jarosław Maciejewski (1924-1987), historyk literatury z Uniwersytetu im. Adama Mickiewicza w Poznaniu: Poznański Czerwiec po trzydziestu latach, „Przewodnik Katolicki” 1988, nr 26, s. $1,4-5 ;$ nr 27 , s. $4-5,8$.

${ }^{6}$ Sergiusz Sterna-Wachowiak (ur. 1953) - poeta, prozaik, autor scenariuszy teatralnych, radiowych i telewizyjnych.

7 S. Sterna-Wachowiak, Symbol i rana: Czerwiec 1956 w poezji i prozie, „Kronika Miasta Poznania" 1995, nr 4, s. 61-95.

${ }^{8}$ Stefan Drajewski (ur. 1960) - dziennikarz, krytyk literacki i teatralny.

${ }^{9}$ Czarny czwartek. Wiersze o Poznańskim Czerwcu'56, wybór i wstęp S. Drajewski, Poznań 2006. Por.: W. Albrecht-Szymanowska, Bibliografia Poznańskiego Czerwca 1956, pod red. Z. Trojanowiczowej, wyd. I, Poznań 1996, s. 121-123.

10 Ł. Bukowski, Tren dla Romka Strzałkowskiego, „Gazeta Wyborcza” nr 149(8756) z 28 czerwca 2016 r., dodatek „Wyborcza Poznań”, s. 2; M. Kaźmierska, Projekt Bunt 56 na rocznicę Poznańskiego Czerwca. Bez martyrologii, „Gazeta Wyborcza” z 10 czerwca 2016 r.; M. Kaźmierska, Treny z ulicy Kochanowskiego, „Gazeta Wyborcza” nr 146(8753) z 24 czerwca 2016 r., dodatek „Magazyn Poznański”, s. 2; Świat z perspektywy buntu naszego powszedniego, "Gazeta Wyborcza” nr 135(8742) z 11/12 czerwca 2016 r., dodatek „Wyborcza Poznań”, s. 5 (rozmowa Marty Kaźmierskiej z Przemysławem Prasnowskim); Treny z ulicy Kochanowskiego na 60. rocznice Czerwca '56, „Gazeta Wyborcza” nr 147(8754) z 25/26 VI 2016 r. i 148(8755), dodatek „Wyborcza Poznań”, s. 2.

${ }^{11}$ Czesław Michniak (1918-2012) - pisarz, dziennikarz.

12 C. Michniak, Opowiadania poznańskie, wyd. I, Poznań 1957, s. 127-133. 
początku 1958 r. Lech Bądkowski ${ }^{13}$ pisał Huśtawkę, która ukazała się dopiero w 1984 r. ${ }^{14}$ W 1966 r. w Instytucie Literackim w Paryżu opublikowana została powieść Piotra Guzy ${ }^{15}$ Krótki żywot bohatera pozytywnego ${ }^{16}$, napisana między czerwcem 1964 r. a sierpniem 1965 r. Również w tej dekadzie ${ }^{17}$ Bogusław Kogut ${ }^{18}$ stworzył opowieść Jeszcze miłość ${ }^{19}$, a Marian Grześczak ${ }^{20}$ Odyseja, odyseja ${ }^{21}$. W 1980 r. ukazało się pierwsze wydanie powieści Krystyny Kofty ${ }^{22}$ Wióry 23 , o której Przemysław Czapliński napisał, że „[..] rewindykuje historię wcześniejszą, pokazując, że Czerwiec wynurzył się z bram, zaułków, podwórek, że jego fundamentem nie była rozbudzona świadomość polityczna lecz raczej pragnienie normalności" ${ }^{24}$. W 1986 r. w Paryżu ukazało się opowiadanie Jerzego Korczaka ${ }^{25}$ Nieznaczny ruch gąsienicy ${ }^{26}$, natomiast Andrzej Górny ${ }^{27}$

${ }^{13}$ Lech Bądkowski (1920-1984) - pisarz, dziennikarz, kaszubski działacz polityczny, kulturalny i społeczny.

${ }^{14}$ L. Bądkowski, Huśtawka, Olsztyn-Białystok 1984.

15 Piotr Guzy (ur. 1922) - pisarz, na emigracji od 1957 r., pracownik BBC i Radia Wolna Europa.

${ }^{16}$ P. Guzy, Krótki żywot bohatera pozytywnego, seria: Biblioteka Kultury, t. 123, Paryż 1966; wyd. II foto-offsetowe, seria: Biblioteka Kultury, t. 351, Paryż 1982 - przedruk: Krakowskie Towarzystwo Wydawnicze, Kraków 1986; wyd. II, Wydawnictwo Nowik, Opole 2015; wydanie niemieckie: Kurzer Lebenslauf eines positiven Helden, Frankfurt am Main 1968. O tej książce Gustaw Herling-Grudziński powiedział: „Jest to jedna z najwybitniejszych książek polskich, jakie ukazały się ostatnio i w kraju i na emigracji. Witam w Panu nowego pisarza o wielkim talencie”, za F. Śmieja, Zapomniane książki, „Przegląd Polski” maj 2012, s. 4. Zob. też S. Gawliński, Emigracyjne rozrachunki ze stalinizmem po 1956 r., cz. II, Piotr Guzy: „Krótki żywot bohatera pozytywnego" (1966), „Dekada Literacka” 1992, nr 13, s. 4.

17 W latach: 1958, 1963, 1966 - według informacji pod tekstem.

18 Bogusław Kogut (1925-1987) - poeta, prozaik, poseł na Sejm PRL II kadencji (1957-1961).

${ }^{19}$ B. Kogut, Jeszcze miłość, Kraków: I wyd. 1967, II wyd. 1970, IV wyd. 1974, wyd. III Warszawa 1973.

${ }^{20}$ Marian Grześczak (1934-2010) - poeta, dramaturg, eseista, tłumacz literatury pięknej.

${ }^{21}$ M. Grześczak, Odyseja, odyseja, Warszawa: I wyd. 1976, II wyd. 1979, III wyd. 1983, powieść napisana w 1963 r. i w 1974 r. Patrz omówienie: E. Pawlak, Z pióra kleks czerwony , „Polityka” 1981, nr 26, s. 9.

${ }^{22}$ Krystyna Kofta (ur. 1942) - powieściopisarka, autorka utworów scenicznych i książek publicystycznych.

${ }^{23}$ K. Kofta, Wióry, wyd. I Warszawa 1980; wyd. II Poznań 1991; wyd. III poprawione i wyd. IV Warszawa 1996, 2006. Recenzja patrz: „Odra” 1992, nr 7/8, s. 101.

${ }^{24}$ Tekst recenzji z okładki IV wydania.

${ }^{25}$ Jerzy Korczak (ur. 1927) - prozaik, satyryk.

${ }^{26}$ J. Korczak, Nieznaczny ruch gąsienicy, „Kultura” 1986, nr 7/8(466/467), s. 88-101 (wydrukowane bez zgody i wiedzy autora); Wrocław 1992.

27 Andrzej Górny (ur. w 1933) - pisarz, krytyk literacki i teatralny, uczestnik Poznańskiego Czerwca 1956 r., współscenarzysta filmu Poznań '56 (wspólnie z Filipem Bajonem). Patrz np. rozmowy Włodzimierza Branieckiego z Andrzejem Górnym: Dzikość wolności, „Arkusz” 1995, nr 6, s. 10; Ktoś inny otwiera bramy, "Głos Wielkopolski" nr 149(14051) z 28 czerwca 1990 r., s. 4; Powrót do Wietnamu, "Głos Wielkopolski” nr 173(16229) z 26/27 lipca 1997 r., s. 5. 
zaczął publikować fragmenty swojej powieści Krew2². Na przełomie dekady lat osiemdziesiątych i dziewięćdziesiątych ukazały się powieść Ciemnia ${ }^{29}$ Bogusławy Latawiec ${ }^{30}$ i nowela Stanisława Rogali ${ }^{31}$ Rozstrzelano czyjeś serce, będąca częścią pierwszą Rodzinnej ballady ${ }^{32}$. W 1996 r., po 26 latach od momentu powstania, ukazała się powieść Józefa Ratajczaka ${ }^{33} W_{e ̨ z} e^{34}$. Książka, będąca zbiorowym obrazem Polaków lat pięćdziesiątych XX w., kończąca się wydarzeniami w Poznaniu w 1956 r., zdobyła w 1970 r. nagrodę w konkursie literackim ogłoszonym przez Wydawnictwo Poznańskie. Została podpisana umowa wydawnicza, ale cenzura wstrzymała druk ${ }^{35}$. Poznański Czerwiec 1956 r. został odzwierciedlony w 14. tomie cyklu Jeżycjada ${ }^{36}$ Małgorzaty Musierowicz ${ }^{37}$ pt. Kalamburka ${ }^{38}$. W 2016 r. ukazały się dwie fabularyzowane powieści Piotra Bojarskiego osnute na kanwie wydarzeń Poznańskiego Czerw-

28 A. Górny, Krew, wyd. I Warszawa 1989; Krew. Powieść, wyd. II Poznań 1991. Fragmenty ogłoszone: „Przewodnik Katolicki” 1986, nr 26, s. 6, 8; Nasz dzień, „Kultura Niezależna” 1988, nr 37, s. 62-75; Wyrok, „Przekrój” 1991, nr 2400, s. 15-17. Recenzje patrz: B. Latawiec, Zapis zbiorowej euforii i jednostkowej porażki, „Twórczość” 1992, nr 7/8, s. 187-189; S. Sterna-Wachowiak, Czerwiec 1956, czyli powieść, „Akcent” 1993, nr 4, s. 151-153.

${ }^{29}$ B. Latawiec, Ciemnia, wyd. I Warszawa 1989; wyd. II popr. Poznań 1995; wyd. III popr. Szczecin 2012.

30 Bogusława Latawiec (Bogusława Latawiec-Balcerzan, ur. 1939) - prozaiczka, poetka, krytyk literacki, nauczycielka w III Liceum Ogólnokształcącym im. św. Jana Kantego oraz VIII Liceum Ogólnokształcącym im. Adama Mickiewicza w Poznaniu.

31 Stanisław Rogala (ur. w 1948) - historyk literatury, prozaik, dramaturg, eseista.

32 S. Rogala, Rodzinna ballada, wyd. I Kielce 1997; wyd. II Bydgoszcz 2001; „Akcent” 1990, nr 3, s. 63-75. Powieść przedstawia losy bohaterów jednego rodu na tle wydarzeń dziejowych od powstania styczniowego do czasów „Solidarności”. Patrz omówienie: O. Białek, Saga rodziny chłopskiej na tle dwudziestowiecznych wydarzeń, "Akcent” 1999, nr 3/4, s. 173-175; J. Z. Brudnicki, Świętokrzyskie gniazdo, „Świętokrzyski Kwartalnik Literacki” 1997, nr 2, s. 113-115; B. Budzińska, Próba oczyszczenia, "Akant” 2001, nr 9, s. 27; Z. W. Fronczek, Pisarz niezależny, „Nasz Dziennik” 2001, nr 151, s. 11; W. Żukrowski, Panorama dotkliwie przeżytych lat, „Ikar” 1997, nr 12, s. 35.

33 Józef Ratajczak (1932-1999) - poeta i prozaik.

34 J. Ratajczak, Węzet, Poznań 1996. Patrz omówienie: L. Czapliński, Czy te nuty mogą kłamać? , "Arkusz" 1997, nr 1, s. 15; M. Obarski, Portret Polaka lat pięćdziesiatych, „Arkusz" 1997, nr 1, s. 12; P. Śliwiński, „Polonistyka” 1996, nr 8, s. 572.

35 R. Brzezińska, Supet cenzury, „Słowo. Dziennik Katolicki” 1996, nr 142, s. 9. Patrz też zapisy dzienników Józefa Ratajczaka opisujące zmagania z cenzurą: D. Ratajczakowa, Wokót powieści Józefa Ratajczaka „Węzet”. Wstęp i publikacja fragmentów „Dzienników”, „Kronika Miasta Poznania” 2006, nr 2, s. 240-255.

36 Jeżycjada - cykl powieści młodzieżowych Małgorzaty Musierowicz o rodzinie Borejków, których akcja osadzona jest w Poznaniu, a nazwa cyklu (wymyślona przez Zbigniewa Raszewskiego) pochodzi od dzielnicy Jeżyce, gdzie mieszkają bohaterowie. W latach 1977-2015 ukazało się 21 tomów cyklu.

${ }^{37}$ Małgorzata Musierowicz (ur. w 1945) - pisarka, ilustratorka, siostra Stanisława Barańczaka (1946-2014).

${ }^{38}$ M. Musierowicz, Kalamburka, Łódź 2001 i 2009. Patrz recenzje: E. Gruda, Potrafili cierpieć biede, potrafią i obfitować..., czyli Borejków droga przez życie, „Poradnik Bibliotekarza” 2001, nr 9, s. 22-23; G. Leszczyński, Borejkowie. Odstona XIV, „Guliwer” 2001, nr 4, s. 34-36; M. A. Pogoda, 
ca: 1956. Przebudzeni ${ }^{39}$ i Juni ${ }^{40}$. Osobno odnotować należy nieopublikowaną powieść Zenona Bosackiego, ogłoszoną we fragmentach w $1990 \mathrm{r}^{41}$, oraz nowele filmowe - Za późno, za wcześnie, już czas ${ }^{42}$ Andrzeja Górnego i Romek Tomasza Soldenhoffa ${ }^{43}$ z 1986 r.

\section{Film, radio, teatr, sztuki wizualne i plastyczne}

Oryginalne filmy dokumentalne z 28 czerwca 1956 r. nie zostały dotychczas odnalezione, ale informacje o filmowaniu demonstracji przez zagranicznych gości XXV Międzynarodowych Targów Poznańskich (MTP) pojawiały się w niektórych relacjach świadków. Jak wspominał pracownik Zarządu MTP Jan P. Fichna ${ }^{44}$ : „[...] Jedni, bardziej przedsiębiorczy, a posiadający kamery filmowe, pośpieszyli za pochodem manifestujących i utrwalili cały przebieg zdarzeń na taśmie, aby potem czym prędzej przekroczyć granice państwa i dokonać intratnej sprzedaży filmowych dokumentów w Zachodnim Berlinie" $^{45}$. Zapisów filmowych z Poznańskiego Czerwca 1956 r. poszukuje prokurator Mirosław Sławeta, który w Oddziałowej Komisji Ścigania Zbrodni przeciwko Narodowi Polskiemu w Poznaniu prowadzi śledztwo w sprawie Poznańskiego Czerwca 1956 r. ${ }^{46}$ Niestety, pomimo wykrycia na fotografiach z 1956 r. osoby z kamerą w ręku, zapisy filmowe z demonstracji 28 czerwca 1956 r. nie zostały dotychczas odnalezione ${ }^{47}$. Dwa odcinki Polskiej Kroniki

Tym razem serio, „W drodze” 2001, nr 12, s. 97-99; B. Szargot, Wiek Borejków, „Nowe Książki” 2001, nr 7, s. 45.

39 P. Bojarski, Dzień bez operacji, "Gazeta Wyborcza” nr 147(8754) z 25/26 czerwca 2016 r., s. $30-31$.

${ }^{40}$ M. Kaźmierska, Czerwiec w szkatule powieści, "Gazeta Wyborcza” nr 156(8763) z 6 lipca 2016 r., dodatek „Wyborcza Poznań”, s. 5.

${ }^{41}$ Z. Bosacki, Czym byt Czerwiec 1956, "Obserwator Wielkopolski” nr 17(153) z 1 lipca 1990 r., s. 3, 10.

42 A. Górny, „Za późno, za wcześnie, już czas”, „Gazeta Poznańska” z 7 kwietnia 1995 r.

43 T. Soldenhoff, Romek. Opowiadanie filmowe, "Czas Kultury” 1988, nr 6, s. 18-34. Tomasz Soldenhoff (ur. 1955) - poeta.

44 Jan Fichna (1922-2009), pracownik Międzynarodowych Targów Poznańskich w latach 1954-1988.

45 J. P. Fichna, Kończyły się Międzynarodowe Targi Poznańskie, [w:] Poznański Czerwiec 1956, pod red. J. Maciejewskiego i Z. Trojanowiczowej, wyd. II popr. i rozszerzone, Poznań 1990, s. 279-280.

46 Śledztwo w sprawie przestępczych czynów funkcjonariuszy państwa komunistycznego podczas tzw. Wydarzeń Poznańskich (S 23/00/Zk).

47 M. Kozubal, IPN próbuje ustalić, czy ktoś filmowat Czerwiec '56, „Rzeczpospolita” nr 290 z 15 grudnia 2014, s. A3. 
Filmowej z 1956 r. - 28/56 $6^{48}$ i 41/56 ${ }^{49}$, poświęcone zostały m.in. Poznańskiemu Czerwcowi. Zostały tam utrwalone m.in. unikatowe sceny z pogrzebu na Cytadeli Poznańskiej ${ }^{50}$ z udziałem Józefa Cyrankiewicza ${ }^{51}$, Edwarda Gierka ${ }^{52}$

48 Polska Kronika Filmowa nr 28/58, pt.: Po Poznaniu, Wytwórnia Filmów Dokumentalnych Warszawa, temat nr 1, data realizacji: 30 czerwca 1956 r., data wydania: 3 lipca 1956 r., komentarz: Karol Małcużyński, lektor: Andrzej Łapicki, zdjęcia: Wiktor Janik, oprac. dźwiękowe: Stefan Zawarski, montaż: Wacław Kaźmierczak.

49 Polska Kronika Filmowa nr 41/56, pt.: Przed sądem w Poznaniu, Wytwórnia Filmów Dokumentalnych Warszawa, temat nr 1, data realizacji: 27 września 1956 r., data wydania: 3 października 1956 r., komentarz: Karol Małcużyński, lektor: Bogdan Niewinowski, zdjęcia: Roman Wionczek, oprac. dźwiękowe: Halina Hanna Ciecierska, montaż: Ludmiła Niekrasowa.

${ }^{50}$ Na Cytadeli Poznańskiej na Cmentarzu Bohaterów Polskich w kwaterze III pochowanych jest trzynaście ofiar Poznańskiego Czerwca 1956 r.: dziewięciu cywilów (Walenty Cieślik, Andrzej Gliński, Zbigniew Janczewski, Władysław Kaczmarek, Marian Kubiak, Franciszek Lipski, Leszek Raś, Wacław Toma, Feliks Wojewódzki) i czterech przedstawicieli sił rządowych (Ryszard Ficek, Bogdan Frankowski, Kazimierz Graja, Zygmunt Izdebny).

$51 \mathrm{O}$ przemówieniu radiowym Józefa Cyrankiewicza i jego pobycie w Poznaniu patrz: Przemówienie Józefa Cyrankiewicza wygłoszone w dniu 29 czerwca 1956 roku przed mikrofonem Polskiego Radia w Poznaniu, "Głos Wielkopolski” nr 155 z 30 czerwca 1956 r.; Nie żałuje tego przemówienia, „Polityka” nr 49(1544) z 6 grudnia 1986 r., s. 7 (rozmowa Roberta Jarockiego z Józefem Cyrankiewiczem); R. Reczek, Kiedy Cyrankiewicz odrąywat ręce poznaniakom?, „Kronika Wielkopolski” 2013, nr 4, s. 46-59. Patrz też J. Eisler, Wydarzenia poznańskie w Polskim Radiu, „Tygodnik Solidarność" nr 6(43) z 6 lipca 1989 r., s. 10.

52 Edward Gierek przybył do Poznania 28 czerwca 1956 r. jako kierownik Wydziału Przemysłu Ciężkiego KC PZPR, m.in. przemawiał na wspólnym pogrzebie ofiar obu stron na Cytadeli Poznańskiej (zob. Nie ma takiej sity, która zdolna byłaby zawrócić nas z obranej drogi. Przemówienie sekretarza KC PZPR - E. Gierka na uroczystościach pogrzebowych, „Głos Wielkopolski” nr 156 z 1/2 lipca 1956 r., s. 2). Następnie stanął na czele komisji wyjaśniającej przyczyny i przebieg zajść. Patrz np.: B. Januszkiewicz, Gdzie byt E. Gierek 28 czerwca 1956 roku?, "Echo Cegielskiego" 1991, nr 26, s. 1; Z. Rykowski, W. Władyka, Raport Gierka, „Polityka” nr 2(1601) z 9 stycznia 1988 r., s. 14. Rola Edwarda Gierka w wydarzeniach Poznańskiego Czerwca jest o tyle istotna, że to on wskazał na Edwarda Ochaba, I sekretarza KC PZPR, jako osobę, która wydała rozkaz strzelania. Wspomina Edward Gierek: „,[...] zadzwoniłem do Ochaba, by zdać mu sprawozdanie z powagi sytuacji w mieście. Na pytanie, czy należy użyć broni, odpowiedziałem, że mimo dramatyzmu wydarzeń należy za wszelką cenę uniknąć rozwiązania zbrojnego. Wkrótce zadzwonił do mnie szef bezpieczeństwa z Poznania, [...], i domagał się ode mnie rozkazu użycia broni. Odmówiłem wydania takiego rozkazu, zasłaniając się własną niekompetencją oraz wewnętrznym przekonaniem, że należy unikać rozwiązania siłowego. [...] Moja odpowiedź nie zadowoliła wówczas szefa bezpieczeństwa, który zezwolenie na użycie broni wyegzekwował telefonicznie chwilę później od samego Ochaba. Wiem, że tak było, od generała milicji, Pietrzaka. Jego pisemną relację na ten temat widziałem na własne oczy", za J. Rolicki, Edward Gierek: przerwana dekada, Warszawa 1990, s. 35. Bardzo ważny jest ostatni fragment wspomnień Edwarda Gierka, mówiący o pisemnej relacji Komendanta Wojewódzkiego MO ppłk. Tadeusza Pietrzaka, dotyczącej rozkazu strzelania, wydanego przez Edwarda Ochaba. Dokument ten znalazł prokurator Aleksander Woźniak, który w 1998 r. prowadził śledztwo w sprawie Poznańskiego Czerwca 1956 r. z ramienia Okręgowej Komisji Badania Zbrodni przeciwko Narodowi Polskiemu: „[...] Znajdują się jednak i rewelacyjne materiały - mówi A. Woźniak. - Odnalazłem relację Tadeusza Pietrzaka, ówczesnego komendanta wojewódzkiego milicji w Poznaniu, który w piśmie do ministra spraw wewnętrznych użył między innymi takiego sformułowania: „Gdy ban- 
i gen. dyw. Wsiewołoda Strażewskiego ${ }^{53}$ oraz z procesów sądowych „trzech" 54 i „„dziewięciu" 55 , rozpoczętych 27 września 1956 r.

Pierwszym filmem dokumentalnym o Poznańskim Czerwcu 1956 r. był Poznań $1956^{56}$ Tadeusza Litowczenki i Mirosława Kwiecińskiego. Zaletą tego filmu jest fakt, że relacje osób występujących, uczestników wydarzeń, nie są obciążone jeszcze konfabulacją i mitomanią, co występuje już masowo w następnych dekadach. Innym ważnym dokumentem byli Niepokonani $i^{57}$ Marka Drążewskiego ${ }^{58}$, film ukończony w 1984 r. ${ }^{59}$, którego reżyser został dwukrotnie nagrodzony w $1988 \mathrm{r} .{ }^{60}$ Oba te obrazy cechowało przede wszystkim pokazanie po raz pierwszy unikatowych jak na tamte czasy źródeł ikonograficz-

dyckie elementy poturbowały żołnierza, wówczas zrozumiałem, że to już nie demonstranci, ale przeciwnicy naszego ustroju. Wtedy wydałem rozkaz, że gdy tłum będzie atakować należy otworzyć ogień, zgodnie z poleceniem towarzysza Ochaba, który dzwonił, aby użyć broni", za K. Brzezicki, Kto się boi Czerwca '56?, „Głos Wielkopolski” nr 144(16503) z 22 czerwca 1998 r., s. 3. Jest to więc trop, wiodący ku odpowiedzi na pytanie, kto kazał strzelać. W Instytucie Pamięci Narodowej jest też dokument, który wskazuje na Edwarda Gierka i Leona Stasiaka jako tych, którzy wydali rozkaz strzelania. Prawdopodobnie nie wydali go samodzielnie, tylko na polecenie z Warszawy, które miało przyjść z Komitetu d/s Bezpieczeństwa Publicznego (AIPN Po, sygn. IPN Po 570/69/CD, Materiały do udostępnienia do celów służbowych, k. 5: „[...] za zgodą tow. Gierka i Stasiaka, na rozkaz kierownika Wojewódzkiego Urzędu /o godz. 12.20/ nastąpiła pierwsza seria ostrzegawcza", AIPN Po, sygn. IPN Po 05/25, Notatka dot. przebiegu wypadków w Poznaniu w dniach 28-29.VI.1956 r. opracowana na podstawie dotychczas uzyskanych materiałów, k. 25.

53 Wsiewołod Strażewski (1897-1973) - w 1956 r. dowódca Śląskiego Okręgu Wojskiego, którego wojska brały udział w tłumieniu zajść w Poznaniu.

54 Proces o morderstwo kpr. Zygmunta Izdebnego - oskarżenie: Józef Foltynowicz, Jerzy Sroka i Kazimierz Żurek, wyroki od czterech lat więzienia do czterech i pół.

55 Janusz Biegański, Stanisław Jaworek, Stanisław Kaufmann, Łukasz Piotrowski, Józef Pocztowy, Leon Olejniczak, Jan Suwart, Zenon Urbanek, Ludwik Wierzbicki - wyroki zapadły, ale na skutek przemian październikowych oskarżeni wyszli na wolność.

${ }^{56}$ Poznań 1956 (1981), reż. i scen. Tadeusz Litowczenko, Mirosław Kwieciński. Patrz: Poznański film o Czerwcu, "Głos Wielkopolski” nr 150(14357) z 29/30 czerwca 1991 r., s. 10 (rozmowa Anny Plenzer z z Tadeuszem Litowczenko).

${ }^{57}$ Niepokonani (1984), reż. i scen. Marek Drążewski, muzyka Jan A. P. Kaczmarek z Orkiestrą Ósmego Dnia.

${ }^{58}$ Właściwie Andrzej Marek Drążewski.

${ }^{59}$ Większość źródeł błędnie podaje datę produkcji 1981 r. W tym roku została rozpoczęta realizacja filmu, którą ukończono w $1984 \mathrm{r}$. Szerzej o filmie patrz: P. Bikont [pod pseud. Ł.K. Liptus], Tego nie wolno nam ogladać, „Tygodnik Mazowsze” nr 200 z 25 lutego 1987 r., s. 2; Film M. Drążewskiego „Niepokonani”, „Obserwator Wielkopolski” 1990, nr 17, s. 7, 10; Niepokonani, „Tygodnik Demokratyczny” 1989, nr 8, s. 8-9 (rozmowa Ewy Wilcz-Grzędzińskiej z Markiem Drążewskim i Małgorzatą Rodowicz); M. Sułkowski, [rec.], "Arka” 1988, nr 21, s. 128-130; J. Uszyński, Niepokonani, „Przegląd Powszechny” 1989, nr 2, s. 315-318; I.W., Zamiast recenzji, „Grizzly” 1988, nr 6/7, s. 13-14.

60 I Nagroda na Festiwalu Filmów Społeczno-Politycznych w Łodzi (1988), Don Kichot Nagroda Polskiej Federacji Dyskusyjnych Klubów Filmowych przyznana w 1988 r. podczas Lubuskiego Lata Filmowego w Łagowie. 
nych i świadków obu stron konfliktu. W 1984 r. ukazała się w prasie „drugiego obiegu" informacja o zniszczeniu w Wytwórni Filmów Dokumentalnych w Warszawie taśmy z filmem dokumentalnym Marka Drążewskiego pt. Poemat na dziś o Poznańskim Czerwcu ${ }^{61}$.

Ciekawym filmem dokumentalnym jest Paradoks o konduktorze ${ }^{62}$ z 1997 r. w reżyserii Michała Dudziewicza. Narratorem był Zdzisław Wardejn ${ }^{63}$, który podczas Poznańskiego Czerwca 1956 r. - jako szesnastolatek - został aresztowany ${ }^{64}$. Kiedy nie wrócił na noc do domu, matka zaczęła go szukać i w kostnicy rozpoznała go omyłkowo wśród zabitych. Faktyczną ofiarą wskazaną przez Annę Wardejn był 25-letni konduktor Miejskiego Przedsiębiorstwa Komunikacyjnego w Poznaniu - Kazimierz Wieczorek ${ }^{65}$. Przyszłemu aktorowi wystawiono akt zgonu ${ }^{66}$, zorganizowany został pogrzeb i stypa, podczas której Zdzisław Wardejn, wypuszczony z aresztu, wrócił do domu ${ }^{67}$. Kazimierza Wieczorka rodzina odnalazła i rozpoznała dopiero w kwietniu 1957 r. Innej ofierze wydarzeń - Romanowi Strzałkowskiemu ${ }^{68}$ - poświęcone zostały dwa obrazy filmowe. Pierwszy z nich zrealizował Michał Drążewski w 1982 r. pt. Jeszcze czekam... ${ }^{69} \mathrm{~W} 2006 \mathrm{r}$. powstał film 13 lat 13 minut ${ }^{70} \mathrm{w}$ re-

${ }^{61}$ Czerwiec 1956. Filmy, ",Tygodnik Mazowsze” nr 86 z 3 maja 1984 r., s. 2.

62 Paradoks o konduktorze (1997), reż. i scen. Michał Dudziewicz.

${ }^{63}$ Zdzisław Wardejn (ur. 1940), aktor teatralny i filmowy.

64 Akta zatrzymania patrz: Archiwum Instytutu Pamięci Narodowej Oddział w Poznaniu (AIPN Po), Wojewódzki Urząd Spraw Wewnętrznych w Poznaniu [1945] 1983-1990, sygn. IPN Po 04/2390.

65 Został przyjęty w późnych godzinach popołudniowych do Szpitala Miejskiego im. Franciszka Raszei z niegroźnym postrzałem głowy. Po założeniu opatrunku uciekł ze szpitala, następnie w godzinach wieczornych z raną drążącą czaszki został przywieziony do Szpitala Miejskiego im. Józefa Strusia, gdzie o 23.00 zmarł. Pochowany jest na Cmentarzu Komunalnym nr 2 Poznań Junikowo (pole 3/8, rząd 7, grób nr 259), patrz Ł. Jastrząb, „Rozstrzelano moje serce w Poznaniu". Poznański Czerwiec 1956 r. - straty osobowe i ich analiza, Poznań-Warszawa 2006, s. $105,115,126,156,174,191,224,281$.

${ }^{66}$ Akt zejścia i karta zgonu nr 883 Zdzisława Wardejna z 30 VI 1956 r., Archiwum USC w Poznaniu, USC Poznań Stare Miasto.

67 Parz też: Długo wstydziłem się tej opowieści, „,Gazeta Polska” nr 26 z 30 czerwca 2010 r., s. 18 (rozmowa Rafała Kotomskiego ze Zdzisławem Wardejnem); T. Z. Zapert, O jedna stype za dużo, „Gazeta Polska” nr 29 z 21 lipca 2006 r., s. 22; A. Ziemkowski, Poznański Czerwiec 1956. Relacje uczestników, oprac. E.R. Dabertowa, współpraca R. Kurewicz, wyd. II, Poznań 2008, s. 462-464.

${ }^{68}$ Roman Strzałkowski - jego przypadkowa śmierć od postrzału stała się mitycznym, pozbawionym prawdy historycznej, symbolem Poznańskiego Czerwca. Patrz szczegółową, jedyną w historiografii analizę faktycznego udziału i okoliczności śmierci Romana Strzałkowskiego: Ł. Jastrząb, "Rozstrzelano moje serce...", s. 134-153.

69 Jeszcze czekam (1982), reż. Marek Drążewski, scen. Marek Drążewski, Jacek Siwecki, muzyka Jan A. P. Kaczmarek z Orkiestrą Ósmego Dnia. Studio Filmowe im. Karola Irzykowskiego, które wyprodukowało film, otrzymało w 1982 r. Don Kichota - Nagrodę Polskiej Federacji Dyskusyjnych Klubów Filmowych.

7013 lat 13 minut (2006), reż. i scen. Marek Maldis, Grzegorz Łubczyk, prod. Telewizja Polska (Lublin) dla TVP Polonia. 
żyserii Marka Maldisa i Grzegorza Łubczyka ${ }^{71}$, równolegle pokazujący historię Romana Strzałkowskiego i Pétera Mansfelda, który (podobnie jak Roman Strzałkowski) jest mitycznym symbolem rewolucji węgierskiej 1956 r., brał w niej udział, jednak nie został skazany za to na śmierć, tylko za działalność rabunkowo-przestępczą po rewolucji, potraktowaną później jako aktywność opozycyjna. Film nie uwzględnił najnowszych badań i ustaleń historyków polskich ${ }^{72}$ oraz węgierskich ${ }^{73}$, jednak jeden z jego twórców - Marek Maldis otrzymał za niego dyplomy ${ }^{74}$.

Najlepszym - w subiektywnym ujęciu - filmem dokumentalnym jest obraz Grzegorza Brauna pt. Ostatnie powstanie z 1995 r. ${ }^{75}$ i jego kontynuacja Remanenty czerwcowe ${ }^{76}$. Reżyserowi udało się namówić na wspomnienia m.in. Edwarda Gierka i Edmunda Pszczółkowskiego, w 1956 r. przewodniczącego Komitetu ds. Bezpieczeństwa Publicznego oraz jednego z dowódców wojsk pancernych. Po raz pierwszy również zostały wykorzystane akta przechowywane w Urzędzie Ochrony Państwa, co dla wiedzy historycznej o Poznańskim Czerwcu w 1996 r. było nowością77.

Wydarzenia z 28 czerwca 1956 r. były tematem kilkunastu innych filmów dokumentalnych, których nie sposób tu omówić, ale warto wymienić je w ce-

71 W latach 1997-2001 był ambasadorem Polski na Węgrzech.

72 Ł. Jastrząb, Mit Pétera Mansfelda, "Głos Wielkopolski” nr 241(19032) z 14/15 października 2006 r., s. 27; tegoż, Mityczna postać poznańskiego Czerwca, „Dziś” 2006, nr 5(188), s. 148-167; tegoż, Mityczny symbol rewolucji wegierskiej 1956 r., "Dziś” 2006, nr 11(194), s. 176-186; tegoż, Święci chłopcy 1956, „Przegląd” nr 47(361) z 26 listopada 2006 r., s. 38-40 (przedruk: Polska Ludowa 1944-1956, pod red. P. Dybicza, Warszawa 2014, s. 274-279).

${ }^{73}$ L. Eörsi, Mansfeld Péter és kultusza [Péter Mansfeld and his cult], "Népszabadság” 2002, October 22; tegoż, Mansfeld Péter, a megtorlás legfiatalabb áldozata [Péter Mansfeld, the youngest victim of the reprisals], "Rubicon" 2002, No. 11-12, s. 30-33; tegoż, Mansfeld Péter. A valóság és a mítosz [Péter Mansfeld, reality and myth], „Beszélő" 2002, No. 12, s. 46-58; tegoż, Odbrazowiony symbol rewolucji, "Życie Warszawy” nr 169 z 21 lipca 2006 r., s. 14-15; tegoż, Péter Mansfeld. Rzeczywistość i mit, (w:) Ł. Jastrząb, Nieznane źródła do historii Wielkopolski XX w. Powstanie wielkopolskie 1918/1919. Okupacja hitlerowska. Powojenne podziemie zbrojne. Rok 1956. Ksiega pamiatkowa z okazji jubileuszu 85 urodzin doc. dr. Mariana Olszewskiego, Poznań 2013, s. 474-501. László Eörsi - ur. 1955 w Budapeszcie, od 1991 r. pracownik naukowy Instytutu Rewolucji Węgierskiej 1956 r., autor licznych publikacji o wydarzeniach na Węgrzech 1956 r., m.in. obalił mit i legendę Pétera Mansfelda.

${ }^{74}$ Dyplom Honorowy Festiwalu Mediów Człowiek w zagrożeniu w Łodzi (2006); Dyplom Specjalny na Festiwalu Form Dokumentalnych „Nurt” w Kielcach (2006) za „wysokie walory poznawcze, edukacyjne i wychowawcze zawarte w obrazie tragicznych wydarzeń 1956 roku w Polsce i na Węgrzech".

75 Ostatnie powstanie (1995), reż. Grzegorz Braun, scen. Grzegorz Braun, Anna Machcewicz, Paweł Machcewicz, prod. „Prasa i Film” dla Programu 1 TVP.

${ }^{76}$ Remanenty czerwcowe (1996), reż. Grzegorz Braun, prod. „Prasa i Film” dla Programu 1 TVP.

77 Grzegorz Braun przeglądał m.in. akta zabitych o późniejszej sygnaturze IPN BU 0749/15 (dawna sygn. 112/15, 155/15). 
lach poznawczych: Broniliśmy Czerwca ${ }^{78}$, Eki z Małeki na Ubeki ${ }^{79}$, Kalendarium Czerwca $^{80}$, Kule zamiast chleba ${ }^{81}$, Maestro ${ }^{82}, \mathrm{My}$ z Cegielskiego (Robotnicy z Cegielskiego) ${ }^{83}$, Pamiętam Czerwiec ${ }^{84}$, Pasja wedtug Czerwca $1956^{85}$, Pomnik-Pamięć o Czerwcu ${ }^{86}$, Poznań był pierwszy ${ }^{87}$, Czerwiec '56 ${ }^{88}$, Poznańskie powstanie $1956^{89}$, Proces przeciwko miastu, $W$ dzień targowy ${ }^{90}$, Więźniarki ${ }^{91}$, Wizja lokalna 195692, Zapomnieć?, Zmęczeni dyktaturą ${ }^{93}$.

W filmie fabularnym motyw Poznańskiego Czerwca pojawiał się incydentalnie. W 1981 r. Krzysztof Kieślowski nakręcił film Przypadek ${ }^{94}$. Film opowiadający o trzech możliwych drogach życiowych głównego bohatera Witolda Długosza (Bogusław Linda), rozpoczyna się dość sugestywnie i ciekawie nakręconą sceną ze szpitala będącego w środku wydarzeń Poznańskiego Czerwca 1956 r. Kamera umiejscowiona na podłodze filmuje chaos szpitalnego korytarza - m.in. rannego/zabitego ciągniętego po posadzce, który zostawia za sobą ślad krwi. Na pierwszym planie widz dostrzega nogę rannego, który prawdopodobnie umiera. Wątek poznański nie został wycięty przez

78 Broniliśmy Czerwca (2006), reż. Agata Ławniczak.

${ }^{79}$ Eki z Małeki na Ubeki (2006), reż. i scen. Włodzimierz Frąckiewicz, Sławomir Koehler i na tej podstawie Rewolta Eków (2013) tych samych reżyserów.

80 Kalendarium Czerwca (2006), reż. Lena Bojanowska.

${ }^{81}$ Kule zamiast chleba (2006), reż. Tadeusz Owczarzak-Gran.

82 Maestro (2008), reż. i scen. Agata Ławniczak.

${ }^{83}$ My z Cegielskiego (tytuł alternatywny: Robotnicy z Cegielskiego, 2006), reż. Zbysław Kaczmarek.

84 Pamiętam Czerwiec (2006), reż. Agata Ławniczak.

${ }^{85}$ Pasja wedtug Czerwca 1956, reż. Agata Ławniczak.

86 Pomnik - Pamięć o Czerwcu (2006), reż. Tomasz Rostworowski, lub Pomnik (2006), reż. Jacek Kubiak.

87 Poznań byt pierwszy (1996), reż. i scen. Marek T. Nowakowski.

88 Poznań 1956 (2006), reż. Grzegorz Grześkowiak, CVK Studio Filmowe, Estrada Poznańska.

${ }^{89}$ Poznańskie powstanie 1956 (2006), reż. i scen. Krzysztof Magowski. Nagrody: 2006 - Dyplom Specjalny Festiwalu Form Dokumentalnych „Nurt” w Kielcach dla Krzysztofa Magowskiego za „wysokie walory poznawcze, edukacyjne i wychowawcze zawarte w obrazie tragicznych wydarzeń 1956 roku w Polsce i na Węgrzech"; 2013 - Grand Prix Festiwalu Filmów „Czerwiec “76" w Radomiu.

${ }^{90}$ W dzień targowy (2006), reż. i scen. Robert Kaczmarek.

91 Więźniarki (2006), reż. Agnieszka Trojak, produkcja TVN dla Discovery Historia TVN.

92 Wizja lokalna 1956 (1996), reż. Marek T. Nowakowski.

93 Zmęczeni dyktaturą (1981 rozpoczęcie, 1990 zakończenie), scen. i reż. Anna Górna, Lubomir Zając. Patrz: Z. Beryt, Pierwszy film o Czerwcu '56, "Gazeta Poznańska” 1990, nr 148, s. 1; W. Braniecki, Film o Czerwcu 1956, „Głos Wielkopolski” nr 146 z 25 czerwca 1990 r., s. 2; B. Kisiel, Film o Czerwcu 1956 „Zmęczeniu dyktaturą", „Express Poznański” 1990, nr 123; rec. „Obserwator Wielkopolski" 1990, nr 18.

94 Przypadek (1981, premiera 1987), scen. Krzysztof Kieślowski. 
cenzurę z serialu Dom ${ }^{95}$ Jana Łomnickiego. W jednym z odcinków zbierają się pracownicy Fabryki Samochodów Osobowych w Warszawie, by dowiedzieć się, co się dzieje w Poznaniu (telefony są wyłączone). Do akcji wkracza działacz partyjny Stanisław Jasiński (Wirgiliusz Gryń), który uspokaja, że wszystkiego dowiedzą się z gazet, a w Poznaniu rozruchy wywołali imperialistyczni agenci przysłani na Międzynarodowe Targi Poznańskie. Swą wiedzę opiera na „świadomości klasowej”, a robotników pyta w przewrotny sposób: „Jak nie ma gazet, to skąd wiecie, że coś się dzieje?"

W sposób bardzo stereotypowy i, niestety, bardzo nieudolny, przedstawiono Poznański Czerwiec w filmie Giacomo Battiato Karol, człowiek, który zostat papieżem ${ }^{96}$. Wydarzenia zostały pokazane w sposób uproszczony, kalkowy, wręcz fałszywy, obarczony błędami merytorycznymi, by wymienić scenę, w której szpaler milicjantów oddaje serie strzałów wprost do tłumu. Dodatkowo rekwizytorzy i kostiumolodzy nie zadbali o autentyczność mundurów, wyposażenia, użytej broni i pojazdów, śmierć Piotra zaś (Jan Romanowski) - chłopca ze sztandarem, który z okrzykiem „Wolna Polska” biegnie prosto pod karabiny milicjantów i zostaje przez nich zastrzelony, miała symbolizować mityczną śmierć Romana Strzałkowskiego, o której już dziś wiadomo, że była przypadkowa i że chłopak na pewno nie zginął ze sztandarem $\mathrm{w}$ ręku, a prawdopodobnie zdarzenie takie $\mathrm{z}$ jego udziałem nie miało miejsca. Dodatkowe elementy, takie jak: sztywna gra aktorów (np. Ennio Fantastichini jako Mateusz Nowak), charakteryzacja, układ scen i ich sztuczność, patetyczne dialogi, w końcu dubbing, sprawiają, że obraz wydarzeń z 1956 r. jawi się groteskowo. Duże wątpliwości budzi też scena słuchania przez studentów w sali wykładowej relacji radiowej z Poznania, kiedy wiadomo, że żadne informacje $\mathrm{z}$ miasta, a zwłaszcza radiowe, nie wychodziły w skutek blokady informacji, natomiast Radio Wolna Europa pierwszą informację nadało dopiero o godz. 23.0028 czerwca $1956 \mathrm{r} .{ }^{97}$

W 1996 r. (22 listopada) premierę miał film Filipa Bajona Poznań ' $56^{98}$, obraz szeroko komentowany i dyskutowany. Pierwsze sygnały o produkcji filmu fabularnego o Poznańskim Czerwcu 1956 r. można odnaleźć w 1994 r.99

95 Dom (1980-2000, premiera 1980, 25 odcinków), odcinek 9. Po obu stronach muru (1982), reż. Jan Łomnicki, scen. Jerzy Janicki, Andrzej Mularczyk.

${ }^{96}$ Karol, człowiek, który zostat papieżem (2004, premiera 2005), scen. Giacomo Battiato.

97 J. Hajdasz, Poznański Czerwiec w programach Rozgłośni Polskiej RWE, [w:] Ku wolności. Powstanie Poznańskie 1956, pod red. M. Jędraszewskiego, Poznań 2006, s. 285-297; J. Nowak-Jeziorański, Wojna w eterze, wyd. II, Kraków 2005; K. Pątek, Poznański Czerwiec 1956 w programach Rozgłośni Polskiej Radia Wolna Europa, [w:] Poznański Czerwiec 1956, pod red. S. Jankowiaka i A. Rogulskiej, seria: Konferencje IPN t. 2, Warszawa 2002, s. 79-84.

98 Poznań '56, (1996), reż. Filip Bajon, scen. Filip Bajon, Andrzej Górny.

99 S. Kmiecik, Film „Czas gniewu” czeka na reżysera, "Głos Wielkopolski” z 9 czerwca 1994 r. 
Ogłoszony został konkurs na scenariusz filmowy ${ }^{100}$, pojawiały się sygnały, że film wyreżyseruje Andrzej Wajda ${ }^{101}$ i że zagra w nim Robert de Niro ${ }^{102}$, oraz pogłoski o finansowaniu filmu z niejasnych źródeł ${ }^{103}$. Ostatecznie za reżyserię zabrał się Filip Bajon ${ }^{104}$, który stworzył scenariusz razem z Andrzejem Górnym $^{105}$. Zdjęcia rozpoczęły się w grudniu 1995 r. na ulicach Poznania. Poznański Czerwiec w tym filmie osnuty jest wokół historii dwóch chłopców - Piotrka (syna robotnika, Mateusz Hornung) i Darka (syna funkcjonariusza UB, Arkadiusz Walkowiak). Widz obserwuje ich wędrówki po mieście ogarniętym strajkiem, na tle wielkiego chaosu, potoku ludzi, strzałów znikąd, a wszystko utrzymane w czarno-białej scenerii zdjecć Łukasza Kośmickiego, ze świetną muzyką Michała Lorenca. Film zdobył wiele nagród ${ }^{106}$, natomiast w środowisku poznańskim został przyjęty dość chłodno ${ }^{107}$.

W 2016 r. został ogłoszony konkurs Poznań '56 na 56-sekundowy film nagrany dowolną techniką, ale nawiązujący w przesłaniu do wydarzeń Poznańskiego Czerwca 1956 r. W Kapitule Nagrody zasiedli: kompozytor Jan A.P. Kaczmarek, reżyser Filip Bajon, operator Artur Reinhart i scenarzy-

\footnotetext{
100 W. Braniecki, 60 scenariuszy filmu „Czerwiec '56", "Głos Wielkopolski” z 16 sierpnia $1994 \mathrm{r}$.

101 (bar), Wajda 1956, „Gazeta Wyborcza” z 28 czerwca 1994 r., dodatek „Gazeta Wielkopolska" z 28 czerwca 1994 r., s. 1; W. Braniecki, „Czerwiec '56" A. Wajdy?, „Głos Wielkopolski” z 7 czerwca $1994 \mathrm{r}$.

102 J. Podolski, Czy Robert de Niro zagra w filmie o Poznańskim Czerwcu?, „Express Poznański” 1994, nr 231, s. 1-2.

103 Film o Czerwcu '56 roku tylko za czyste pieniadze, "Gazeta Wyborcza” z 28 czerwca 1994 r., dodatek "Gazeta Wielkopolska” z 28 czerwca 1994 r., s. 4.

104 Patrz np.: W. Braniecki, Szczun - z Filipem Bajonem o Poznaniu, o jego wielkopolskiej trylogii filmowej rozmowy prawie o wszystkim, Poznań 1998; Śmierć jak sznytka chleba, "Gazeta Poznańska” z 21 lipca 1995 r. (z Filipem Bajonem rozmawia Anna Kot).

${ }^{105}$ F. Bajon, A. Górny, Poznań '56 (scenariusz filmu), Poznań 1997.

106 1996, Festiwal Polskich Filmów Fabularnych w Gdyni: Nagroda Specjalna Jury, Nagroda za zdjęcia - Łukasz Kośmicki, Nagroda za scenografię - Anna Wunderlich, Przemysław Kowalski, Nagroda za kostiumy - Małgorzata Braszka, Nagroda za dźwięk - Marek Wronko, Nagroda za rolę dziecięcą - Mateusz Hornung, Arkadiusz Walkowiak; nominacja do Złotych Lwów w 1996 r. dla Filipa Bajona; 1997, Tarnowska Nagroda Filmowa - Nagroda Jury Młodzieżowego „Kamerzysta”; Międzynarodowy Festiwal Filmowy „Złoty Rycerz” w Moskwie, nagroda za reżyserię dla Filipa Bajona i za zdjęcia dla Łukasza Kośmickiego.

107 Reżyserowi zarzucano m.in., że aktorzy mówią gwarą śląską, a nie poznańską, używają przekleństw i wulgaryzmów, krytykowano minimalizm scenograficzny i wpadki, gdzie np. sceny letnie były kręcone w zimie (aktorom leciała para $\mathrm{z}$ ust), a słoneczne dni kręcono podczas ulewy, co markowano scenami przy fontannie, gdzie robotnicy mieli się chłodzić i chlapać wodą dookoła. Również niezrozumiała dla widzów była różna symbolika, np. uciekające z ZOO wielbłądy. Patrz np. recenzje: W. Kot, Teledysk z rewolucji, „Wprost” nr 49(732) z 8 grudnia 1996 r.; R. Leszczyński, "Gazeta Wyborcza” 1997, nr 12, s. 12; P. Machcewicz, "Polityka” 1997, nr 6, s. 56-57; J. Wróblewski, „Kino” 1997, nr 1, s. 21; S. Zuber, Wokót filmu „Poznań “56”, "Głos Wielkopolski” z 27 grudnia 1996 r.
} 
sta Andrzej Maleszka ${ }^{108}$. Uroczyste wręczenie nagród odbyło się 27 czerwca 2016 r. w Poznaniu, pierwsze trzy miejsca zajęli kolejno: Michał Krygier, Bartosz Stań i Jakub Januszewski ${ }^{109}$.

Na deski teatralne Poznański Czerwiec trafił podczas „karnawału Solidarności" - 20 czerwca 1981 r. w Teatrze Nowym w Poznaniu odbyła się premiera spektaklu Oskarżony: Czerwiec Pięćdziesiąt Sześćc ${ }^{10}$ w reżyserii Izabelli Cywińskiej i Janusza Michałowskiego, według scenariusza Izabelli Cywińskiej i Włodzimierza Branickiego. Przedstawienie zagrano 99 razy, setne przedstawienie miało się odbyć 13 grudnia 1981 r. Dopiero w 1991 r. Teatr Animacji w Poznaniu wystawił przedstawienie Zaczęło się to w czerwcu ${ }^{111}$. Z okazji pięćdziesiątej rocznicy Poznańskiego Czerwca Izabela Cywińska i Jerzy Kalina przygotowali widowisko Czerwiec '56, wystawione 28 czerwca 2006 r. na pl. Adama Mickiewicza w Poznaniu. W przedstawieniu wzięli udział aktorzy poznańskich scen: Teatru Nowego im. Tadeusza Łomnickiego, Teatru Polskiego, Polskiego Teatru Tańca oraz Teatru Biuro Podróży. Tego samego dnia poznański Teatr Ósmego Dnia wystawił spektakl Czas matek, w który wplecione zostały wątki matek ofiar Poznańskiego Czerwca. Dzień później inny poznański teatr - Teatr Strefa Ciszy na terenie dawnych Zakładów Odzieżowych "Modena” zaprezentował Naukę latania, spektakl z przewodnim motywem wolności. W 2013 r. miało miejsce bardzo ważne wydarzenie teatralne: 23 listopada odbyła się w Teatrze Nowym im. Tadeusza Łomnickiego w Poznaniu premiera spektaklu Gorączka czerwcowej nocy ${ }^{112}$. Spektakl, który w stolicy Wielkopolski przeszedł bez echa, odbrązawia Poznański Czerwiec, odziera go z mitów i legend, pokazując w sposób obiektywny prawdę, m.in. o Romanie Strzałkowskim, o którym aktorzy mówią do matki (w tej roli Daniela Popławska): „Nas pani z pamięci okradła. Wychodziła se pani tę pamięć, O tym pani Romku. Co w patriotycznej tradycji wychowany. Z drzew-

108 B. Dąbkowski, Nakręć 56 sekund emocji i ważnych wspomnień, "Głos Wielkopolski” nr 82(21933) z 8 kwietnia 2016 r., s. 22-23; L. Waligóra, 56 sekund na wolność! Wielki konkurs filmowy w rocznice Czerwca, „Nasza Historia” (Wielkopolska) 2016, nr 6(31), s. 26.

109 B. Dąbkowski, N. Kowalski, W 56 sekund przedstawili Czerwiec '56, „Głos Wielkopolski” nr 149(22000) z 28 czerwca 2016 r., s. 2-3.

110 Oskarżony: Czerwiec Pięćdziesiąt Sześć wedtug zeznań na procesach i relacji świadków Poznańskiego Czerwca 1956, premiera 20 czerwca 1981 r., reż. Izabella Cywińska, Janusz Michałowski, scen. Izabella Cywińska, Włodzimierz Braniecki, scenografia Michał Kowarski, ruch sceniczny Leszek Czarnota, songi Michał Piotrowski, kierownictwo muzyczne Andrzej Lajborek. Scenariusz w opracowaniu Sergiusza Sterna-Wachowiaka w: W. Braniecki, Czerwiec '56 pod Poznańskimi Krzyżami, Poznań 2006, s. 73-97.

111 P. Kępiński, Powstanie poznańskie w oczach zwyczajnych ludzi, „Express Poznański” 1991, nr 121, s. 1-2.

112 Goraczka czerwcowej nocy, premiera 16 listopada 2013 r., zdjęcie z afisza 29 czerwca 2016 r., reż. i scenografia Remigiusz Brzyk, dramaturgia Tomasz Śpiewak. Patrz recenzje, np.: P. Dobrowolski, Święto bez świętych, "Teatr" 2014, nr 2, s. 49-51; S. Drajewski, Plakatowe mielizny mieszają się z podniostymi emocjami, „Polska. Głos Wielkopolski” 2013, nr 269, s. 19. 
cem w ręce padł. A to gówno prawda. A nie było tak". 13 grudnia 2014 r. poznański Teatr Ósmego Dnia wystawił po raz pierwszy spektakl Dwie niepodobne historie $^{113}$, będący dialogiem pomiędzy Ewą Wójciak, córką mecenasa Juliusza Wójciaka, obrońcy w procesach poznańskich, i Adamem Suwartem, synem Jana Suwarta, jednego z oskarżonych uczestników Poznańskiego Czerwca. W kolejną rocznicę Poznańskiego Czerwca 1956 r., 19 czerwca 2016 r., zaprezentowane zostało przy ul. Młyńskiej ${ }^{114} \mathrm{w}$ Poznaniu widowisko multimedialno-teatralne pt. Stukot/Czerwiec '56115, zorganizowane przez Stowarzyszenie Teatralne Antrakt ${ }^{116}$. W ramach 25. Malta Festival Poznań 28 czerwca 2016 r. na pl. Adama Mickiewicza wystawione zostało multimedialne widowisko Ksenofonia. Symfonia dla Innego w reżyserii Jana Komasy (choreografia Mikołaj Mikołajczyk, muzyka Bartek Wąsik i Miłosz Pękala z Kwadrofonik we współpracy z Royal String Quartet) ${ }^{117}$. Również Teatr Ósmego wystawił 25 i 26 czerwca festiwalowe widowisko "Gniew"118.

Jeżeli chodzi o audycje i reportaże radiowe, to udało się ustalić następujące przedsięwzięcia zrealizowane w poznańskim Polskim Radiu (obecnie Radio Merkury ${ }^{119}$ ): Broniłem Czerwca $1956^{120}$ o obrońcach z procesów poznańskich - Michale Grzegorzewiczu i Stanisławie Hejmowskim; Kędy siew padnie $z$ drowy ${ }^{121}$, w którym autorkom po raz pierwszy udało się dotrzeć i porozma-

113 Dwie niepodobne historie (2015), reż. Adam Suwart, Ewa Wójciak.

114 Przy ul. Młyńskiej w Poznaniu znajdowało się w 1956 r. Centralne Więzienie (obecnie Areszt Śledczy), podczas Poznańskiego Czerwca 1956 r. demonstranci wtargnęli na jego teren i wypuścili ponad 250 więźniów, wśród których nie było żadnego skazanego z przyczyn politycznych.

115 Stukot/Czerwiec '56 (2016), reż. Janusz Stolarski, dramaturgia Adam Suwart, oprawa muzyczna Krzysztof „Wiki” Nowikow, videomaker Tomasz Jarosz, kurator Lech Raczak, producent Renata Stolarska.

116 S. Drajewski, Stukot drewniaków jak w 1956 roku, „Głos Wielkopolski” nr 143(21994) z 21 czerwca 2016 r., s. 4; tegoż, Stukot: poznaniacy ciągle pamiętają, "Głos Wielkopolski” nr 141(21992) z 18/19 czerwca 2016 r., s. 6; M. Kaźmierska, Szukając dźwięków Czerwca, "Gazeta Wyborcza” nr 137(8744) z 14 czerwca 2016 r., dodatek „Wyborcza Poznań", s. 4.

117 S. Godlewski, Taniec zamiast pocisków, "Gazeta Wyborcza” nr 151(8758) z 30 czerwca 2016 r., dodatek „Wyborcza Poznań”, s. 5; A.S. Dębowska, Buntownicy 56, "Gazeta Wyborcza” nr 151(8758) z 30 czerwca 2016 r., s. 19.

118 S. Drajewski, "Gniew" to komiksowa opowieść o Poznańskim Czerwcu, zrealizowana przez Teatr Ósmego Dnia, "Głos Wielkopolski” nr 149(22000) z 28 czerwca 2016 r., s. 11; M. Nawrocka-Leśnik, Sens buntu, „IKS” 2016, nr 6(296), s. 8.

119 Patrz: Zachowane w dźwięku, czyli Poznański Czerwiec '56 w archiwum Radia Merkury SA, wyboru dokonał i wstępem opatrzył P. Frydryszek, „Kronika Miasta Poznania” 2006, nr 2, s. 129-154; A. Zarzycki, Tu mówi Poznań. Od Radja Poznańskiego do Radia Merkury SA, Poznań 2016.

${ }^{120}$ Bronitem Czerwca 1956 (1980/1981), realizacja Agata Ławniczak, Barbara Miczko-Malcher.

${ }^{121}$ Kędy siew padnie zdrowy (1980/1981), realizacja: Agata Ławniczak, Barbara Miczko-Malcher, reportaż nagrodzony na Ogólnopolskim Konkursie Reportażu Radiowego w 1981 r. Fragmenty obu tych audycji znalazły się na płycie CD wydanej w 2006 r. przez Wojewódzką 
wiać ze Stanisławem Matyją, jednym z nieformalnych przywódców strajku z 1956 r.; Poznański Czerwiec '56 - relacja - komentarze ${ }^{122}$; Tak tajne, że przed przeczytaniem spalone $e^{123}$ o losach nagrań z procesów poznańskich.

Utwory muzyczne poświęcone Poznańskiemu Czerwcowi są skromne. W 2006 r. Jan A.P. Kaczmarek skomponował Oratorium 1956, dzieląc utwór na cztery części: Poranny polonez, Tren dla Romka, Poznań-Budapeszt i Jednym tchem. Oratorium wykonali muzycy Filharmonii Poznańskiej ichór Poznańskie Słowiki, a poprowadził ich Michał Nesterowicz z Filharmonii Bałtyckiej (28 czerwca). Utwór nawiązał również do rewolucji węgierskiej 1956 r., chórzyści bowiem zaśpiewali w oryginale fragment Pieśni narodowej Sandora Petöfiego. Kompozytor Jacek Sykulski napisał utwór Missa 1956. Składająca się z pięciu części kompozycja została wykonana podczas porannej mszy 28 czerwca na pl. Adama Mickiewicza. W projekcie wzięli udział: Poznański Chór Chłopięcy, Chór Akademicki UAM, Orkiestra Symfoniczna Akademii Muzycznej w Katowicach. W tym samym roku odbył się również koncert (29 czerwca) Szacunek dla Poznańskiego Czerwca, podczas którego Mezo i Owal wykonali utwór hip-hopowy Czerwiec ${ }^{124}$. 60. rocznica Poznańskiego Czerwca została również uczczona m.in. utworem na osiem trąbek, taśmę i urządzenia mobilne, przygotowanym przez poznańskiego jazzmana Macieja Fortunę ${ }^{125}$, który koncert zagrał 28 czerwca 2016 r. (wykonał m.in. utwór Jazzem we władze ludowa) wraz z muzykami z Katedry Jazzu i Muzyki Estradowej Akademii Muzycznej im. Ignacego Jana Paderewskiego w Poznaniu. 27 czerwca w Centrum Kultury Zamek w Poznaniu odbył się koncert multimedialny Romek w reżyserii Jerzego Fryderyka Wojciechowskiego ${ }^{126}$. Z wydarzeń muzycznych należy również odnotować koncert zespołu De Press 26 czerwca w hali nr 7 Zakładów Cegielskiego z brawurowym wykonaniem wiersza Kazimiery Iłłakowiczówny Rozstrzelano moje serce w Poznaniu ${ }^{127}$. W stylu rockowym utwór Zmiana warty poświęcony Poznańskiemu Czerwcowi

Bibliotekę Publiczną i Centrum Animacji Kultury w Poznaniu. Patrz też: A. Ławniczak, Obrazki, [w:] Ku wolności, s. 299-321.

122 Poznański Czerwiec '56 - relacja - komentarze (1981), realizacja Piotr Frydryszak.

${ }^{123}$ Tak tajne, że przed przeczytaniem spalone, realizacja: Barbara Miczko-Malcher, Ryszard Wojtowicz.

${ }^{124}$ Ukazał się na płycie Eudaimonia 16 października 2006 r. w wytwórni UMC Records.

125 B. Dąbkowski, Trąbkami przypomną nam o Czerwcu '56, „Głos Wielkopolski” nr 131(21982)

z 7 czerwca 2016 r., s. 4; K. Kurkiewicz, Jazzem we władzę. Z bimby, „Gazeta Wyborcza” nr 145(8752) z 23 czerwca 2016 r., dodatek "Wyborcza Poznań”, s. 5.

126 P. Rezmer, "Romek". Historia buntu, "Głos Wielkopolski” nr 145(21996) z 23 czerwca 2016 r., s. 4.

127 M. Zaradniak, Grupa De Press zagrała w Cegielskim, by uczcić Poznański Czerwiec, "Głos Wielkopolski" nr 148(21999) z 27 czerwca 2016 r., s. 2. 
przygotowała grupa Omni mOdO wraz z Danielem Moszczyńskim i to autorzy utworu ${ }^{128}$.

Z innych przedsięwzięć artystyczno-kulturalnych, można zwrócić uwagę na: znaczki pocztowe ${ }^{129}$, monety ${ }^{130}$, kartki pocztowe, rysunki ${ }^{131}$, wpinki, plakietki, medale okolicznościowe ${ }^{132}$, a nawet bilety tramwajowe ${ }^{133}$, które pojawiały się w sposób incydentalny (często w tzw. drugim obiegu w latach osiemdziesiątych $\mathrm{XX}$ w.), są rozproszone, a zagadnienie nie jest opracowane. Warto również odnotować murale - trzy już na stałe wpisały się w krajobraz miejski ${ }^{134}$, czwarty powstał w czerwcu 2016 r. na ścianie przy bramie głównej Zakładów Cegielskiego według projektu i wykonania Marka Laskowskiego ${ }^{135}$. Podczas Nocy Muzeów w 2016 r. w Oddziale Instytutu Pamięci Narodowej w Poznaniu zostały zaprezentowane bardzo interesujące i praktyczne z punktu widzenia edukacji materiały - puzzle $z$ fotografiami z Poznańskiego Czerwca i grę pamięciową tzw. memory.

W 2006 r. Franciszek Starowieyski namalował alegorię Poznańskiego Czerwca - obraz o wymiarach 2,9 na 8 metrów przedstawiający boginię Nike, robotników i czerwoną gwiazdę jako „alegorię czerwonej zarazy”136. Dzieło wzbudziło kontrowersje z powodu nagich postaci i błędów merytorycznych w dedykacji poświęconej Pamięci 74 ofiar Czerwca 1956 i 13 rozstrzelanych żotnierzy. W 2016 r. obraz na co dzień niedostępny (wisi na ścianie w gmachu

128 Tegoż, Nie tylko jazzem, ale i rockiem we władzę ludowa, "Głos Wielkopolski” nr 149(22000) z 28 czerwca 2016 r., s. 2.

${ }^{129}$ Emitowano np. w latach: 1990, 1996 i 2006. Patrz też H. Brzozowski, Poznański Czerwiec '56 na znaczkach poczty podziemnej 1982-1989, Poznań 1996.

${ }^{130}$ W 1996 r. ukazała się moneta dziesięciozłotowa (nakład 13050 szt., waga 14,14 g, średnica 32 mm, metal Ag 925) 40 rocznica wydarzeń poznańskich 1956 r., wg projektu Ewy Tyc-Karpińskiej. Awers monety: wizerunek orła ustalony dla godła Rzeczypospolitej Polskiej, po bokach orła oznaczenie roku emisji 19-96, pod orłem napis: ZŁ 10 ZŁ, w otoku napis: RZECZPOSPOLITA POLSKA, poprzedzony oraz zakończony pięcioma perełkami. Rewers monety: tłum manifestantów w symbolicznym ujęciu, na jego tle napis - 40 ROCZNICA / WYDARZEŃ / POZNAŃSKICH / CZERWIEC / 1956.

131 J. Mulczyński, Z inspiracji 1956 roku. Ikonografia Poznańskiego Czerwca 1956 roku, „Kronika Miasta Poznania" 2006, nr 2, s. 262-277.

132 Np. w 1981 r. jako cegiełki Społecznego Komitetu Budowy Pomnika Poznańskiego Czerwca. Patrz Z. Bartkowiak, Poznański Czerwiec 1956 w medalierstwie, Poznań 1996.

133 Z okazji pięćdziesiątej rocznicy Poznańskiego Czerwca w 2006 r. bilety miały na odwrocie nadrukowany napis rocznicowy.

${ }^{134}$ Ul. Jana Henryka Dąbrowskiego 472, ul. Górna Wilda 61, ul. 28 Czerwca 1956 r. 153 (2011).

135 Symbole pamięci Czerwca '56, „Głos Wielkopolski” nr 134(21985) z 10 czerwca 2016 r., s. 11.

136 T. Morawski, Franciszek Starowieyski obraz - alegoria Poznańskiego Czerwca '56, „Biuletyn Powiatu Poznańskiego" 2006, nr 6(72), s. 38-40. 
biur zarządu H. Cegielski - Poznań S. A.) został na kilka godzin 28 czerwca udostępniony publiczności ${ }^{137}$.

Poznański Czerwiec nie miał i nie ma do dziś szczęścia w muzealnictwie. Skromna ekspozycja dotycząca Czerwca '56 miała miejsce w Odwachu w 1981 r., ale jako część większej wystawy poświęconej dziejom przemysłu i klasy robotniczej w Wielkopolsce. Następne czasowe wystawy odbyły się w latach: 1991, 1994, 1996, 2000, 2001. Dopiero 10 czerwca 2002 r. ówczesne Wielkopolskie Muzeum Walk Niepodległościowych ${ }^{138}$ otworzyło skromną ekspozycję w Centrum Kultury Zamek w Poznaniu jako Muzeum Poznańskiego Czerwca 1956 r. ${ }^{139} 4$ października 2007 r. - po wielu perturbacjach $^{140}$ - otwarta została nowa lokalizacja, również w dawnym Zamku

137 K.M. Kaźmierczak, W rocznicę Czerwca '56 będzie można zobaczyć alegorię Starowieyskiego, „Głos Wielkopolski” nr 139(21990) z 16 czerwca 2016 r., s. 8.

${ }^{138}$ W 1961 r. powstało Muzeum Historii Ruchu Robotniczego im. Marcina Kasprzaka. W 1991 r. wojewoda poznański przejął placówkę, nadając jej nazwę Wielkopolskie Muzeum Historyczne w Poznaniu. W wyniku komunalizacji Muzeum wróciło do miasta w drugim półroczu 1992 r. i jako instytucja samorządowa jest od 1993 r. w całości finansowana z budżetu Poznania. W 1997 r. placówka otrzymała nazwę Wielkopolskie Muzeum Walk Niepodległościowych w Poznaniu, a od 2015 r. Wielkopolskie Muzeum Niepodległości. Posiada oddziały: Muzeum Powstania Wielkopolskiego 1918-1919, Muzeum Armii „Poznań”, Muzeum Martyrologii Wielkopolan - Fort VII, Muzeum Uzbrojenia, Muzeum Powstania Poznańskiego Czerwiec 1956. Patrz: Uchwała nr 48/411/61 Prezydium Rady Narodowej m. Poznania z dnia 22 grudnia 1961 r. w sprawie utworzenia jednostki budżetowej pn. „Muzeum Historii Ruchu Robotniczego im. Marcina Kasprzaka w Poznaniu"; Uchwała nr LXV/480/II/97 Rady Miasta Poznania z dnia 16 grudnia 1997 r. w sprawie zmiany nazwy Wielkopolskiego Muzeum Historycznego w Poznaniu i nadania statutu; Uchwała nr XCV/1083/III/2002 Rady Miasta Poznania z dnia 27 sierpnia 2002 r. w sprawie: zmiany statutu Wielkopolskiego Muzeum Walk Niepodległościowych w Poznaniu. - Na podstawie art. 6, w związku z art. 5 ust. 1 i 3 ustawy z dnia 21 listopada 1996 r. o muzeach (Dz. U. z 1997 r. nr 5, poz. 24 z późniejszymi zmianami) i art. 18 ust. 2 pkt 15 ustawy z dnia 8 marca 1990 r. o samorządzie gminnym (Dz. U. z 2001 r. nr 142, poz. 1591 z późniejszymi zmianami), w porozumieniu z Ministrem Kultury, Rada Miasta Poznania; Uchwała Nr VII/38/VII/ 2015 Rady Miasta Poznania z dnia 10 lutego 2015 w sprawie zmiany nazwy Wielkopolskiego Muzeum Walk Niepodległościowych i nadania nowego statutu (Dziennik Urzędowy Województwa Wielkopolskiego z 3 marca 2015 r., poz. 1172).

139 Były to dwie sale i korytarz o łącznej powierzchni około $90 \mathrm{~m}^{2}$, do których wchodziło się od strony Ogrodu Zamkowego. Szerzej patrz: W. Grajewski, Muzeum Poznańskiego Czerwca '56, „Przegląd Wielkopolski” 2002, nr 3/4, s. 106-108.

${ }_{140}$ P. Bojarski, Doczekać otwarcia muzeum, „Gazeta Wyborcza” nr 155(5163) z 5 lipca 2006 r., dodatek „Poznań”, s. 2; tegoż, Muzeum Czerwca - w czerwcu, "Gazeta Wyborcza” nr 19(5329) z 23 stycznia 2007 r., dodatek „Poznań”, s. 3; tegoż, Muzeum Czerwca w zamku dopiero w 2007 roku?, „Gazeta Wyborcza” nr 228(5235) z 29 września 2006 r., dodatek „Poznań”, s. 3; tegoż, Przymiarki do daty przed Muzeum Czerwca, "Gazeta Wyborcza” nr 99(5407) z 27 kwietnia 2007 r., dodatek „Poznañ”, s. 4; tegoż, W przyspieszonym tempie powstaje Muzeum Poznańskiego Czerwca, "Gazeta Wyborcza” nr 201(5208) z 29 sierpnia 2006 r., dodatek „Poznań”, s. 4; tegoż, A. Przybylska, Muzeum Czerwca gotowe dopiero we wrześniu, "Gazeta Wyborcza" nr 120(5428) z 24 maja 2007 r., dodatek „Poznań”, s. 1; K. Matysik, Muzeum będzie dzielone dyktą, "Głos Wielkopolski” nr 120(19214) z 24 maja 2007 r., s. 10; tejże, Muzeum z rocznym poślizgiem, "Głos Wielkopolski” nr 44(19138) 
Cesarskim, ale w podziemiach od strony ul. Święty Marcin ${ }^{141}$, placówka otrzymała nazwę Muzeum Powstania Poznańskiego - Czerwiec 1956 Wielkopolskiego Muzeum Niepodległości ${ }^{142}$.

\section{Historiografia, konferencje naukowe}

Pierwsze próby naukowego opracowania zagadnienia Poznańskiego Czerwca 1956 r. zostały podjęte już w 1957 r. Antoni Gąsiorowski zebrał informacje prasowe o wydarzeniach ${ }^{143}$, Bohdan Gruchman i Bogumił Ziółek zbadali poziom życia mieszkańców Poznania w latach 1949-1955144, a Zbigniew Żechowski podjął próbę opisania przyczyn wybuchu strajku w Zakładach Cegielskiego w Poznaniu ${ }^{145}$. Potem na 25 lat zapadła słynna „kurtyna milczenia" Władysława Gomułki, cytowana w większości wstępów do opracowań o Poznańskim Czerwcu ${ }^{146}$, chociaż w 1971 r. na Zachodzie ukazał się pierwszy tekst będący próbą opisania przebiegu Poznańskiego Czerwca 1956 r., au-

z 21 lutego 2007 r., s. 10; E. Podolska, Nie zdaża z muzeum, "Gazeta Poznańska” 2005, nr 294, s. 8; F. Springer, Muzeum Czerwca 1956 czeka na eksponaty, "Głos Wielkopolski” nr 21(19115) z 25 stycznia 2007 r., s. 11.

141 Patrz np.: S. Drajewski, Muzeum Powstania Poznańskiego Czerwca 1956 roku, „Kronika Wielkopolski" 2008, nr 1(125), s. 111-114; P. Henski, Muzeum Poznańskiego Czerwca 1956 otwarte, „Panorama Wielkopolskiej Kultury” 2007, nr 9/10(40/41), s. 1-2.

142 Muzeum, niestety, nie prezentuje najnowszej wiedzy historycznej o Poznańskim Czerwcu, jako konsultanci zapraszani są kombatanci, którzy nie posiadają odpowiedniej wiedzy merytorycznej. Wystawa zawiera wiele błędów, uproszczeń: prezentowana tam lista ofiar liczy 60 osób, chociaż już dawno była ustalona liczba 57; na wykazie muzealnym ofiar Poznańskiego Czerwca 1956 r. jest osoba, która pod wpływem alkoholu powiesiła się w 1959 r.; zamiast zdjęcia ofiary jest jej szwagier; a tabliczka wisząca na ekspozycji wprowadza zwiedzających w błąd, że: „[...] do dziś nie jest ustalona liczba ofiar, historycy zgodnie stwierdzają - na pewno ponad 100". Nie jest podane ani źródło tej informacji, ani nie ma nazwisk historyków. Patrz też recenzja ekspozycji Ł. Jastrząb, Indyk ze sprężyna, "Trybuna” nr 240(5357) z 13/14 października 2007 r., s. 2.

143 Głosy o "wypadkach poznańskich” (28 czerwca 1956 r.), zebrał A. Gąsiorowski, „Kronika Miasta Poznania" 1957, nr 1-2, s. 170-186. Por. Dokumentacja prasowa 1956, r. V, Warszawa 1957.

${ }^{144}$ B Gruchman, B. Ziółek, Przyczynek do badań stopy życiowej mieszkańców Poznania w latach 1949-1955, „Kronika Miasta Poznania” 1957, nr 1-2, s. 5-29.

145 Z. Żechowski, Z ekonomicznych źródet sytuacji strajkowej w Zakładach im. H. Cegielskiego wiosna 1956 r., „Kronika Miasta Poznania” 1957, nr 3-4, s. 43-56.

146 „[...] w tym, co się stało w Poznaniu, widziałem tylko tragedię zaszłą między braćmi, a nie walkę przeciwstawnych sobie sił. I z tej tragedii nikomu nie wolno robić bohaterstwa. Zdarzają się nawet $\mathrm{w}$ rodzinach tragiczne wypadki. I chociaż rodzina dotknięta takim nieszczęściem nigdy o nim zapomnieć nie może, to zawsze stara się jak najgłębiej zapuścić nad swoją tragedią żałobną kurtynę milczenia”, "Trybuna Ludu” nr 154(3029) z 7 czerwca 1957 r., s. 5 (fragment przemówienia wygłoszonego przez Władysława Gomułkę 5 czerwca 1957 r. do pracowników Zakładów Cegielskiego). 
torstwa Ewy Wasowskiej Poznań 1956147. Literaturę powstałą po 1981 r. można pogrupować wg różnych kategorii, o czym poniżej.

Zostały napisane wstępne syntezy, ale Poznański Czerwiec wciąż nie ma monografii. Pierwszą książką o tych wydarzeniach był Poznański Czerwiec $1956^{148}$ pod redakcją Jarosława Maciejewskiego i Zofii Trojanowiczowej. Pierwsze wydanie książki było wielkim sukcesem jak na tamte czasy, przygotowana w ciągu kilku miesięcy, na ówczesnym rynku antykwarycznym osiągała wysokie ceny. Drugie wydanie z 1990 r. ${ }^{149}$ niestety zalegało półki księgarskie, 10.000 egzemplarzy miało zostać przeznaczone na przemiał, ale wykupiła je po cenie makulatury "Solidarność”. Pomimo tego w 2006 r. - nie wiadomo, w jakim celu - ukazało zostało trzecie wydanie ${ }^{150}$, będące kopią tego z 1990 r. Jeszcze w dekadzie lat osiemdziesiątych ukazała się książka ${ }^{151}$ Jana Ptasińskiego ${ }^{152}$, opierająca się na materiałach Urzędu Bezpieczeństwa. Opracowania Antoniego Czubińskiego ${ }^{153}$ z tego okresu mają charakter ogólny, niepogłębiony ${ }^{154}$ i pomimo że $\mathrm{w}$ podtytule jednej z broszur była zapowiedź, iż jest to fragment planowanej monografii, takowa nie powstała do dziś ani spod pióra Antoniego Czubińskiego, ani nikogo innego. W 1992 r. Poznański Czerwiec został opisany w kontekście walk ulicznych okresu Polski Ludowej ${ }^{155}$. W 1993 r. Paweł Machcewicz opublikował Polski rok 1956, który uważam za najlepszą - pomijając potrzebę uaktualnienia źródeł - syntezę wydarzeń 1956 r., opartą mocno na źródłach. Podobne ujęcie dotyczące całego roku 1956 r. zaprezentowała Paulina Codogni w 2006 r. ${ }^{156}$ Ogólnymi synteza-

147 Poznań 1956 - Grudzień 1970, Biblioteka Kultury, t. 202, seria: „Dokumenty”, z. 35, Paryż 1971.

148 Poznański Czerwiec 1956, pod red. J. Maciejewskiego i Z. Trojanowiczowej, Poznań 1981.

149 Poznański Czerwiec 1956, pod red. J. Maciejewskiego i Z. Trojanowiczowej, wyd. II popr. i rozszerzone, Poznań 1990.

150 Poznański Czerwiec 1956, pod red. J. Maciejewskiego i Z. Trojanowiczowej, wyd. III, Poznań 2006.

${ }^{151}$ J. Ptasiński, Wydarzenia poznańskie czerwiec 1956, Warszawa 1986. Zob. też tegoż, Drugi zwrot. Gomutka u szczytu powodzenia, Warszawa 1988.

152 Jan Ptasiński (1921-2015) - w czerwcu 1956 r. zastępca przewodniczącego Komitetu do Spraw Bezpieczeństwa Publicznego.

153 A. Czubiński, Czerwiec 1956 w Poznaniu. Fragmenty przygotowywanej przez autora monografii nt. wydarzeń czerwcowych w Poznaniu, seria: Z dziejów Wielkopolski, Poznań 1986; tegoż, Kryzys polityczny 1956 roku w Polsce. Geneza i skutki, Poznań 1982; tegoż, Poznań Czerwiec 1956-1981, seria: Z dziejów Wielkopolski, Poznań 1981.

154 O syntetycznym, ogólnym podejściu naukowym Antoniego Czubińskiego do Poznańskiego Czerwca 1956 r. zob. W. Olszewski, Straty osobowe Poznańskiego Czerwca 1956 r. wedtug Antoniego Czubińskiego, [w:] Śladami mistrza. Prace z historii najnowszej dedykowane profesorowi Antoniemu Czubińskiemu, pod red. S. Sierpowskiego, Poznań 2013, s. 51-56.

155 A. Dudek, T. Marszałkowski, Walki uliczne w PRL 1956-1989, Kraków 1992.

156 P. Codogni, Rok 1956, Warszawa 2006. 
mi zajmowali się: Jerzy Eisler ${ }^{157}$ (również wspólnie z Robertem Kupieckim ${ }^{158}$ ), Rafał Reczek ${ }^{159}$, Andrzej Werblan ${ }^{160}$. Z początkiem lat dziewięćdziesiątych ukazały się dwie pozycje autorstwa Macieja Romana Bombickiego, będące połączeniem zbioru wspomnień i wydawnictwa źródłowego ${ }^{161}$. W 2001 r. ${ }^{162}$ i 2006 r. ${ }^{163}$ ukazała się książka Edmunda Makowskiego, będąca pierwszą próbą całościowego, syntetycznego opisania Poznańskiego Czerwca, niestety oparta na niepełnej bazie źródłowej, brak chociażby tej, do której miał dostęp Paweł Machcewicz już w 1993 r. Do udanych syntez można zaliczyć pracę Janusza Karwata z 2006 r. ${ }^{164}$, specjalizującego się w badaniu wojskowych aspektów Poznańskiego Czerwca; tą tematyką zajmował się również Edward Jan Nalepa, autor klasycznej, wyważonej w opiniach i ocenie książki o udziale Wojska Polskiego w wydarzeniach ${ }^{165}$. Badania nad problematyką ofiar Poznańskiego Czerwca 1956 r. prowadzone były przez trzy osoby: Aleksandra Ziemkowskiego, Mariana Jana Potograbskiego ${ }^{166}$ i Łukasza Jastrząba ${ }^{167}$. Lista 57 ofiar opracowana przez tego ostatniego autora została potwierdzona przez pion śledczy Instytutu Pamięci Narodowej i na stałe weszła do obiegu naukowego, kończąc tym samym dyskusje nad tym zagadnieniem. W historiografii Poznańskiego Czerwca są również książki, które rzuciły bardzo zły cień na tę tematykę. Mowa o komiksie 1956. Poznański Czerwiec $^{168}$, który jest przepełniony błędami merytorycznymi, zbudowany został na zasadzie uproszczeń, powielanych kalek, schematów, został poddany

157 J. Eisler, „Polskie miesiące” czyli kryzys(y) w PRL, Warszawa 2008.

158 J. Eisler, R. Kupiecki, Na zakręcie historii - rok 1956, Warszawa 1992.

159 R. Reczek, Życie społeczno-polityczne w Wielkopolsce w latach 1956-1970, Poznań 2008.

160 A. Werblan, Stalinizm w Polsce, wyd. II, Warszawa 2009.

161 M. R. Bombicki, Polski Październik '56. Początek drogi, Poznań 1993; tegoż, Poznań '56, Poznań 1992.

162 E. Makowski, Poznański Czerwiec 1956 - pierwszy bunt społeczeństwa w PRL, Poznań 2001. 2006.

163 Tegoż, Poznański Czerwiec 1956 - pierwszy bunt społeczeństwa w PRL, wyd. II, Poznań

164 J. Karwat, J. Tischler, 1956. Poznań. Budapeszt, Poznań 2006.

165 E.J. Nalepa, Pacyfikacja zbuntowanego miasta. Wojsko Polskie w Czerwcu 1956 r. w Poznaniu w świetle dokumentów wojskowych, Warszawa 1992.

166 M.J. Potograbski, Powstanie Poznańskie 1956 roku. Wspomnienia rodzin o zabitych, niektóre relacje manifestacji, walki i obrony, Poznań 1997. Autor za ofiary Poznańskiego Czerwca 1956 r. uznał m.in. dziesięcioletnią dziewczynkę, która zmarła 8 lipca 1956 r. w Słupsku z powodu śpiączki cukrzycowej podobno na wskutek szoku po informacji o śmierci Romana Strzałkowskiego oraz osobę, która w 1959 r. pod wpływem alkoholu powiesiła się. Listę i treść książki autoryzował poprzez napisanie wstępu Stanisław Jankowiak z Instytucie Historii Uniwersytetu im. Adama Mickiewicza w Poznaniu.

167 Ł. Jastrząb, „Rozstrzelano moje serce w Poznaniu”. Poznański Czerwiec 1956 r. - straty osobowe i ich analiza, Poznań-Warszawa 2006.

168 M. Jasiński, J. Michalski, W. Tkaczyk, W. Żwikiewicz, 1956: Poznański Czerwiec, Poznań 2006. 
druzgocącej krytyce ${ }^{169}$. Z jego treści można się dowiedzieć m.in., że aktywny udział w zajściach brały prostytutki, są również narysowane - nie wiadomo, w jakim celu - wątki erotyczno-obyczajowe pomiędzy uczestnikami. Drugą książką jest opracowanie Kingi Przyborowskiej dotyczące "procesu trzech" czyli procesu kryminalnego morderców kaprala Zygmunta Izdebnego, zlinczowanego podczas Poznańskiego Czerwca. Autorka - pracownica Muzeum Poznańskiego Czerwca 1956 r. - zadedykowała mordercom książkę, a w treści zostali oni przedstawieni jako ofiary systemu. Książka powstała na bazie pracy magisterskiej, której promotorem był Stanisław Jankowiak z Instytutu Historii Uniwersytetu im. Adama Mickiewicza w Poznaniu (UAM), napisał również pochwalny wstęp do wydania książkowego. Wydanie za pieniądze samorządu poznańskiego tej pozycji zakończyło się wielkim skandalem protestowali m.in. kombatanci i uczestnicy oraz środowiska naukowe ${ }^{170}$.

Osobnej prezentacji wymagają publikacje pokonferencyjne ${ }^{171}$, które za każdym razem były bardzo wartościowe, wnoszące wiele nowego do problematyki Poznańskiego Czerwca. Wydawnictwa takie ukazały się w latach: $1981^{172}, 1996^{173}, 1998^{174}, 2002^{175}, 2006^{176}, 2007^{177}$. Jeżeli chodzi o wydawnictwa źródłowe, dorobek jest jeszcze ciągle skromny. Pierwsze źródła w formie zwartej ukazały się w 1995 r. i był tam w zasadzie w przewadze jeden dokument - ogólny raport Urzędu Bezpieczeństwa ${ }^{178}$. Ukazały się później zbiory

169 Ł. Jastrząb, Komiksowa tendencyjność. Recenzja komiksu „1956: Poznański Czerwiec”, ",Zeszyty Komiksowe" 2006, nr 5, s. 82-83. Por. S. Zajączkowski, Atrakcyjność komiksu historycznego na tle wymagań stawianych twórcom komiksowym przez historię i sztukę, "Pamięć i Sprawiedliwość" 2013, nr 2, s. 111-134.

170 K.M. Kaźmierczak, Miasto wydało ksiażkę zrównująca kryminalistów z bohaterami Czerwca ‘56, „Polska. Głos Wielkopolski” nr 219(19940) z 18 września 2009 r., s. 2-3; tegoż, Uczestników linczu zrównano z ofiarami, „Polska. Głos Wielkopolski” nr 219(19940) z 18 września 2009 r., s. 1; M. Mikołajczyk, Chwała mordercom, „Nie” nr 37(989) z 10 września 2009 r., s. 14.

171 Konferencje zostały omówione poniżej.

172 Wydarzenia czerwcowe w Poznaniu 1956. Materiaty z konferencji naukowej zorganizowanej przez Instytut Historii UAM w dniu 4.V.1981 roku, pod red. E. Makowskiego, wyd. I i II [w różnych formatach], Poznań 1981.

173 Poznański Czerwiec w świadomości i historii, pod red. A. Górnego, Poznań 1996.

174 Przełomowy rok 1956. Poznański Czerwiec. Polski Październik. Budapeszt. Materiały międzynarodowej konferencji naukowej Poznań, 26-27 czerwca 1996 roku, pod red. E. Makowskiego i S. Jankowiaka, Poznań 1998.

175 Poznański Czerwiec 1956, pod red. S. Jankowiaka i A. Rogulskiej, Warszawa 2002.

176 Poznański Czerwiec '56. Sens pamięci, pod red. W. Ratajczaka, Poznań 2006. Patrz też okolicznościowy numer „Kroniki Miasta Poznania” 2006, nr 2.

177 Poznański Czerwiec 1956. Uwarunkowania - Przebieg - Konsekwencje. Materiały z międzynarodowej konferencji naukowej. Poznań 22-23 czerwca 2006, pod red. K. Białeckiego i S. Jankowiaka, Poznań 2007.

178 S. Jankowiak, E. Makowski, Poznański Czerwiec 1956 w dokumentach, Poznań 1995. 
dokumentów o udziale wojska ${ }^{179}$ i milicji ${ }^{180}$, oraz bardzo ciekawa publikacja listów napływających w 1956 r. do Polskiego Radia ${ }^{181}$. Duży zbiór dokumentów został wydany w 2012 r. ${ }^{182}$, nie wiadomo tylko, dlaczego wśród autorów tego opracowania jest nieżyjący już wówczas od dwunastu lat Edmund Makowski, który nie miał i nie mógł mieć dostępu do tych dokumentów. Istotne są również opublikowane protokoły z VI i VII Plenum Komitetu Centralnego PZPR ${ }^{183}$, dokumenty partyjne z $1956 \mathrm{r}^{184}$ oraz akty oskarżenia wobec uczestników Poznańskiego Czerwca ${ }^{185}$.

Pierwszy zbiór wspomnień zebrał i wydał w 1995 r. ${ }^{186}$ na prawach rękopisu w dwudziestu egzemplarzach Aleksander Ziemkowski. Zbiór ten doczekał się reedycji w dwóch wydaniach - w latach $2006^{187}$ i $2008^{188}$. Ukazały się jeszcze w 2006 r. dwa skromne wydawnictwa, będące pokłosiem konkursów wspomnieniowych ${ }^{189}$. Część wspomnieniową ma również zbiór tekstów o charakterze popularyzatorskim, opublikowany również w 2006 r. ${ }^{190}$ Jest też cała grupa książek dotyczących pamięci Poznańskiego Czerwca ${ }^{191}$, eduka-

179 Po obu stronach barykady. Wojska Polskie w Poznaniu 1956 w dokumentach, wstęp i oprac. E.J. Nalepa, Warszawa 1998.

180 Ł. Jastrząb, Milicja Obywatelska w Poznańskim Czerwcu 1956 r. Wybór źródet, Torun 2011.

181 "My głodujemy - my chcemy chleba". Poznański Czerwiec 1956 r. w listach opublikowanych w Biuletynach Biura Listów Komitetu do Spraw Radiofonii "Polskie Radio", wybór i oprac. G. Majchrzak, red. K. Bittner, wstęp K. Bittner, G. Majchrzak i P. Zwiernik, Poznań 2011.

182 Poznański Czerwiec 1956. Wybór dokumentów, wybór i oprac. S. Jankowiak, R. Kościański, E. Makowski, R. Reczek, Poznań 2012.

183 Protokoty VI i VII Plenum Komitetu Centralnego Polskiej Zjednoczonej Partii Robotniczej z 1956 r., oprac., wybór i przygotowanie do druku W. Władyka, W. Janowski, Warszawa 2007.

${ }^{184}$ Dokumenty centralnych władz Polskiej Zjednoczonej Partii Robotniczej marzec-listopad '56, oprac., wybór i przygotowanie do druku M. Jabłonowski, W. Janowski, A. Skrzypek, W. Władyka, Warszawa 2009.

185 Powstanie Poznańskie 1956 roku. Akty oskarżenia, wprowadzenie i oprac. J.M. Grabus, Poznań 2010.

186 A. Ziemkowski, Poznański Czerwiec 1956. Relacje uczestników, Poznań 1995 [druk na prawach rękopisu].

187 A. Ziemkowski, Poznański Czerwiec 1956. Relacje uczestników, oprac. redakcyjne E.R. Dabertowa, współpraca R. Kurewicz, Poznań 2006.

188 A. Ziemkowski, Poznański Czerwiec 1956. Relacje uczestników, oprac. redakcyjne E.R. Dabertowa, współpraca R. Kurewicz, wyd. II, Poznań 2008.

189 Rok 1956 - 28 czerwca. Wspomnienia i refleksje 50 lat później, Poznań 2006; Widziałem powstanie. Czerwiec 1956. Wspomnienia uczestników powstania poznańskiego w czerwcu 1956 roku, nadestane na konkurs „Przewodnika Katolickiego", Poznań 2006.

190 Ku wolności. Powstanie Poznańskie 1956, pod red. M. Jędraszewskiego, Poznań 2006.

191 E.R. Dabertowa, A. Łuczak, Walka o pamięć Czerwca '56. Obchody 26 rocznicy Czerwca w 1982 r. (stan wojenny), Poznań 2001 [w 2006 r. był dodruk sfinansowany przez Kuratorium Oświaty w Poznaniu]; P. Grzelczak, Poznański Czerwiec 1956. Walka o pamięć w latach 1956-1989, Poznań 2016; E. Najwer, Komitet 80/81. Pięć kamyków Dawida, wstęp S. Sterna-Wachowiak, Poznań 2006. 
cji192, budowy pomnika193, prezentacji wydarzeń bardziej z punktu widzenia społecznego ${ }^{194}$ lub kroniki wydarzeń ${ }^{195}$. Jeżeli chodzi o albumy z fotografiami dokumentującymi wydarzenia, to odnotować trzeba pierwsze wydawnictwo z 1981 r. - wybór zdjęć ze zbiorów Społecznego Komitetu Obchodów 25. Rocznicy Poznańskiego Czerwca 1956 r. ${ }^{196}$ Do klasyki przeszła relacja fotograficzna Leszka Paprzyckiego, który z okna przy ul. Poznańskiej fotografował zajścia na ul. Jana Kochanowskiego - doczekała się aż trzech wydań ${ }^{197}$. Bardzo udany album, zasługujący na wznowienie lub wersję z innymi fotografiami, ukazał się nakładem Instytutu Pamięci Narodowej w 2003 r. ${ }^{198}$ Są również wydawnictwa dokumentujące budowę pomnika Poznańskiego Czerwca 1956 r. ${ }^{199}$

Również środowisko kombatantów i uczestników Poznańskiego Czerwca ma swój wkład w historiografię wydarzeń. Henryk Ladorski w 1992 r. napisał książkę 200 , o której jeden z recenzentów - Zenon Bosacki - napisał: „nie wszystko, co pisze autor, jest prawdziwe”, a raziło go zwłaszcza "bezkrytyczne powtarzanie sugestii o udziale przebranych żołnierzy radzieckich"201. Recenzji podjął się także Edmund Makowski ${ }^{202}$, dla którego „szczegółowość niektórych informacji skłaniają do powątpiewania, czy można takie szczegóły zapamiętać [...] oraz, że w książce tej brakowało [...] informacji, skąd au-

192 S. Jankowiak, F. Leśniak, B. Zatorska, Echo Poznańskiego Czerwca '56. Materiały pomocnicze, Poznań 2006; Poznań. Czerwiec '56. Notes edukacyjny, wybór i oprac. P. Miakota i M. Stachura, red. A. Grupińska i J. Wawrzyniak, scenariusze lekcji P. Miakota, M. Stachura, Warszawa 2008; Robotnicy wyszli na ulicę. Materiały do zajęć o Poznańskim Czerwcu 1956 roku dla nauczycieli i uczniów, pod red. B. Kuświka, Poznań 2011.

193 E. R. Dabertowa, M. Lenartowski, Dzień po dniu. Wznoszenie pomnika Poznańskiego Czerwca 1956, Poznań 2006; tychże, Pomnik Poznańskiego Czerwca 1956. Symbol pamięci i sprzeciwu, Poznań 1996.

${ }^{194}$ Między pokoleniami. Czerwiec '56, pod red. W. Bergandy, K. Bocheńskiej, L. WrócińskiejSławskiej, Wągrowiec 2007.

195 Echa Czerwca. Kronika Obchodów 50 Rocznicy Powstania Poznańskiego 1956 roku, Poznań 2006.

196 H. Batura, B. Borowiak, S. Wiktor, Poznań - czerwiec 1956, [wybór zdjęć ze zbiorów Społecznego Komitetu Obchodów 25. Rocznicy Poznańskiego Czerwca 1956 r. - Barbara Szczepańska], wydano na zlecenie Społecznego Komitetu Obchodów 25. Rocznicy Poznańskiego Czerwca 1956 MKZ NSZZ „Solidarność” Wielkopolska, Poznań 1981.

197 L. Paprzycki, Ulica Kochanowskiego 28/29 czerwca 1956. Fotografie i relacja, Poznań 1981; wyd. II popr. i uzup., Poznań 1996; wyd. III popr., Poznań 2012.

198 S. Jankowiak, P. Machcewicz, A. Rogulska, Zranione miasto. Poznań w czerwcu 1956 roku, Poznań-Warszawa 2003.

199 Od pomystu do realizacji. Pomnik Poznańskiego Czerwca 1956 w fotografii Jerzego Unierzyskiego, Poznań 2005.

${ }^{200}$ H Ladorski, Niepokonani. Poznań '56, Poznań 1992.

201 Z. Bosacki, Dziennikarz dnia ważnego, „Gazeta Poznańska” nr 145 z 25 czerwca 1993 r., s. 4.

202 E. Makowski, Poznański Czerwiec 1956 roku, „Kronika Wielkopolski” 1993, nr 1(64), s. $138-139$. 
tor uzyskał wiadomości o opisywanych wydarzeniach". Budzącą duże zdumienie jest również książka Stanisława Zubera ${ }^{203}$, według której autor podczas Poznańskiego Czerwca „wziął ster w swoje ręce” i, mając do dyspozycji „2 tony kamieni”, zebrał „oddziały Powstańcze”, a następnie „powierzono mu dowodzeniem Powstaniem" Poznańskiego Czerwca 1956 r. Funkcja „dowodzenia Powstaniem" nie przeszkodziła Stanisławowi Zuberowi w opuszczeniu Poznania i udania się do Rokietnicy, gdzie w "miejscowej gospodzie GS spożył obiad". Potem wrócił do Poznania, "gdzie trwały zacięte" walki, ale „wygasały one ze względu na przemęczenie i brak żywności” ${ }^{204}$. Związki kombatanckie udokumentowały swoją działalność w formie książkowej ${ }^{205}$.

Warto również wymienić poznańskich dziennikarzy zajmujących się Poznańskim Czerwcem, np.: Leszek Adamczewski, Piotr Bojarski, Zenon Bosacki, Krzysztof M. Kaźmierczak, Sławomir Kmiecik. Odnotowania warta jest również praca naukowa Andrzeja Choniawko 206 , mająca swoje efekty tylko w artykułach naukowych, ale oparta na mocnych podstawach źródłowych.

Poznański Czerwiec 1956 r. doczekał się wielu konferencji naukowych. W 1981 r. zostały zorganizowane dwie ${ }^{207},: 4$ maja 1981 r. w Instytucie Historii UAM odbyła się pierwsza sesja, podczas której uwagę zwróciły teksty: Andrzeja Choniawko o przebiegu wydarzeń ${ }^{208}$, Jana Sandorskiego o procesach poznańskich ${ }^{209} \mathrm{i}$ komunikat Wiesława Olszewskiego systematyzujący zajścia pod gmachem Wojewódzkiego Urzędu ds. Bezpieczeństwa Publicznego przy ul. Jana Kochanowskiego w Poznaniu ${ }^{210}$, który był pierwszym i przez 25 lat ${ }^{211}$ jedynym w literaturze przedmiotu jakimkolwiek niezależnym opisem sytuacji

203 S. Zuber, Przyczyny wybuchu Powstania Poznańskiego w czerwcu 1956 roku, wyd. II, Poznań 1998.

204 Tamże, s. 142-148.

205 D. Matelski, Działalność Stowarzyszenia "Poznański Czerwiec '56" w latach 1989-2008, Poznań 2008; K. Przyborowska, Od 20 lat Niepokonani, Poznań 2010. W 2006 r. Stowarzyszenie „Poznański Czerwiec '56" wydało pozycję zatytułowaną Stowarzyszenie "Poznański Czerwiec '56". Broszurka jest uboga merytorycznie, nie ma prawie żadnej treści, jest w zasadzie zbiorem nieczytelnych kserokopii zdjęć, dobranych w sposób chaotyczny, bez żadnego klucza. Wydawnictwo to nie posiada ISBN, zostały wydane dwie serie - jedna bez autora na okładce, gdyż według informacji zawartej w stopce redakcyjnej, autorem był czteroosobowy zespół i druga z dodrukowanym na okładce nazwiskiem autora - Jana Wieczorka.

206 Zob.: A. Choniawko, Dokumenty z akt PZPR, „Kronika Miasta Poznania” 2006, nr 2, s. 74-128; tegoż, Powstania czy rewolty? W kręgu terminologii, „Przegląd Zachodni” 2006, nr 3(320), s. 21-48; tegoż, Zachowania polityczne między Czerwcem a Październikiem 1956 roku, "Kronika Miasta Poznania" 2006, nr 2, s. 31-54

${ }^{207}$ Informacje o wydawnictwach pokonferencyjnych zostały omówione w części artykułu dotyczącej literatury.

208 A. Choniawko, Przebieg wydarzeń czerwcowych w Poznaniu.

209 J. Sandorski, Procesy poznańskie z 1956 roku. Tezy obrony i oskarżenia.

210 W. Olszewski, Gmach WUBP jako centralny punkt wydarzeń poznańskich.

211 Zob. Ł. Jastrząb, Poznański czerwiec w relacji pptk. Feliksa Dwojaka, „Przegląd Historyczno-Wojskowy" 2006, nr 4(214), s. 134-162. 
pod gmachem i w jego wnętrzu, nie wiadomo, dlaczego pomijany w historiografii i niecytowany. 27 maja $1981 \mathrm{r}$. zorganizowana została druga sesja, pt. Poznański Czerwiec w świetle nauk społecznych ${ }^{212}$, ale niestety - referaty ${ }^{213} \mathrm{z}$ tej konferencji nie zostały opublikowane. W 1990 r. w Poznaniu zorganizowano sesję naukową Polskie przełomy, podczas której głos zabrali m.in.: Andrzej Choniawko, Andrzej Górny, Jan Sandorski ${ }^{214}$. Rok później odbyła się kolejna sesja Czerwiec poczatkiem sierpnia, w czasie której Zofia Trojanowiczowa sugerowała prowokacyjne podłoże Poznańskiego Czerwca 1956 r., który miał być wywołany przez rządzących ${ }^{215}$. 12 czerwca 1993 r. odbyła się jedna z ciekawszych sesji naukowych w historiografii Poznańskiego Czerwca pt. Poznański Czerwiec w świadomości i historii ${ }^{216}$, podczas której dyskutowano o nazewnictwie tych wydarzeń: bunt, rewolucja, rewolta, rebelia, powstanie ${ }^{217}$. Na uwa-

212 Patrz omówienie: „Biuletyn Informacyjny KZ NSZZ Solidarność HCP” 1981, nr rocznicowy; R. Jarocki, Ponad emocjami, „Literatura” 1981, nr 33, s. 9, 15; Z. Chąciak, Poznańskie sesje naukowe (4 maja i 27 czerwca 1981) poświęcone wydarzeniom czerwcowym w Poznaniu w 1956 r., „Zeszyty Naukowe Wojskowej Akademii Politycznej" 1982, nr 110, s. 196-200; J. Kiwerska, Sesje naukowe w Poznaniu nt. Czerwiec 1956, "Z Pola Walki” 1982, nr 1/2, s. 315-324; A. Labuda, E. Musierowicz, Sygnaty wydawniczo-publicystyczne. Jeszcze o upamiętnieniu i obchodach Poznańskiego Czerwca, „KIK Poznań. Informacje Klubowe" 1981, nr 4, s. 7-8; (mo), Poznański Czerwiec w świetle nauk społecznych, "Ilustrowany Kurier Społeczny" 1981, nr 124, s. 8.

${ }^{213}$ Wygłoszone zostały wówczas następujące referaty: Bogdan Gruchman, Plan 6-letni a warunki bytowe ludności Wielkopolski; Andrzej Kwilecki, Wspomnienia uczestników; Łucja Łukaszewicz, Opinie socjologa o procesach; Jan Sandorski, Procesy poznańskie; Janusz Ziółkowski, Znaczenie Poznańskiego Czerwca; Zbigniew Żechowski, Dokumenty źródłowe dotyczace ekonomiczno-społecznego tła strajku.

214 W. Braniecki, Czerwiec początkiem Sierpnia. Dyskusja upamiętniajaca rok 1956, „Głos Wielkopolski” 1991, nr 144, s. 2; tegoż, Czerwiec początkiem Sierpnia. Zapis głosów w dyskusji, "Głos Wielkopolski” 1991, nr 149; P. Kępiński, Czerwiec początkiem Sierpnia, „Express Poznański” 1991, nr 121, s. 2; Pierwsze ogniwo w tańcuchu zmian, "Gazeta Poznańska” 1991, nr 148, s. 1-2; J. Podolski, Polskie przetomy, „Dzisiaj” 1990, nr 239, s. 3; nr 251, s. 3; R. Zieliński, Bogaty program 35 rocznicy Czerwca '56, „Express Poznański” 1991, nr 122.

${ }^{215}$ R. Zieliński, Prowokacja czy wcześniej zorganizowany ruch, „Express Poznański” 1991, nr 123, s. 1-2.

${ }^{216}$ M. Bajerowicz, To jednak było powstanie..., „Głos Wielkopolski” 1993, nr 135, s. 4; Z. Bosacki, Insurekcja czerwcowa?, „Gazeta Poznańska” 1993, nr 135, s. 1-2; R. Dabertowa, Ostatnia polska insurekcja, "Głos Wielkopolski” 1993, nr 147, s. 12.

${ }^{217}$ Kwestię tę omówił dokładnie A. Choniawko, Powstania czy rewolty?, s. 21-48. Termin „powstanie" absolutnie się nie przyjął, został sztucznie stworzony w 2006 r. przez wąską grupę kombatantów i, niestety, zaakceptowany i promowany przez ówczesne władze Poznania (A. Banasiak, R. Biniak, W. Marciniak, M. Wiza, To było nasze powstanie, "Głos Wielkopolski” nr 33(18824) z 8 lutego 2006 r., s. 16). Zakończyło się to niepowodzeniem, wymyślony termin nie miał żadnych podstaw naukowo-merytorycznych, już w 2006 r. np. historycy warszawscy apelowali o odejście od nazwy "powstanie”, by nie „narazić się na krytykę czy nawet drwinę”, patrz P. Bojarski, Warszawski historyk kontra powstanie, "Gazeta Wyborcza” nr 138(5146) z 14/15 czerwca 2006 r., s. 6. Ciekawy głos w dyskusji wokół nazewnictwa zabrał w 2013 r. Wiesław Olszewski w tekście o badaniach Poznańskiego Czerwca prowadzonych przez Antoniego Czubińskiego (W. Olszewski, Straty osobowe Poznańskiego Czerwca 1956 r., s. 51). Olszewski napisał, że po raz 
gę zwracają wystąpienia Jana Sandorskiego ${ }^{218}$ i Edmunda Makowskiego ${ }^{219}$ dotyczące różnych zagadek i problemów, jakie wówczas, z punktu widzenia tamtego stanu wiedzy, a dziś już rozwiązane, nurtowały badaczy. Natomiast 24 czerwca 1994 r. odbyło się sympozjum pt. Literatura wobec Czerwca ' $56^{220}$. Następne konferencje organizowane były terminach „rocznicowych". W 1996 r., 26-27 czerwca, odbyła się międzynarodowa konferencja pt. Przełomowy rok 1956. Poznański Czerwiec-Polski Październik - Budapeszt, w czasie której dyskusję rozszerzono na aspekty międzynarodowe wydarzeń roku 1956, poruszano nie tylko wątki poznańskie, ale i rewolucji węgierskiej oraz przełomu październikowego w Polsce. 26 czerwca 2001 r. Biuro Edukacji Publicznej Instytutu Pamięci Narodowej - Komisji Ścigania Zbrodni przeciwko Narodowi Polskiemu Oddział w Poznaniu zorganizowało sesję, na której wyróżnić należy przede wszystkim tekst Krystiana Bedyńskiego dotyczący problematyki więziennej Poznańskiego Czerwca ${ }^{221}$, będący uzupełnieniem artykułu tego badacza z 1998 r. ${ }^{222}$ W 2006 r., z okazji pięćdziesiątej rocznicy zajść, odbyły się cztery wydarzenia naukowe: konferencja Poznański Czerwiec '56. Sens pamięci (8 maja), zorganizowana przez Centrum Studiów Otwartych UAM; konferencja w Akademii Obrony Narodowej w Warszawie (13 czerwca); seminarium zorganizowane 16 czerwca przez Instytut Zachodni w Poznaniu pt. Polacy i Niemcy - 17 czerwca 1953 i 28 czerwca 1956 - wspólna przeszłość?; międzynarodowa konferencja Poznański Czerwiec 1956 - uwarunkowania, przebieg, konsekwencje (22-23 czerwca) ${ }^{223}$; panel dyskusyjny To byto powstanie... zorganizowany przez Wydział Teologiczny UAM w Poznaniu; III Międzynarodowy Kongres pt. Kanony kulturowe "Środkowych Europejczyków" wobec nowego ładu europejskiego (6-8 listopada), gdzie zasadniczą treścią była debata pt. Drogi do wolności 1956-2006, zorganizowany przez Fundację Kultury Polskiej Filię

pierwszy o „powstaniu” usłyszał z ust Lecha Trzeciakowskiego podczas sesji naukowej w $1981 \mathrm{r}$. Idąc tym tropem, znalazł recenzję Trzeciakowskiego z 1982 r., który napisał: „[...] mieliśmy wtedy do czynienia z powstaniem robotników poznańskich, którzy wystąpili w obronie ideałów socjalistycznych” (L. Trzeciakowski, Poznański Czerwiec 1956, "Kwartalnik Historyczny” 1982, nr 1, s. 158). A zatem - według Wiesława Olszewskiego - teza o socjalistycznym podłożu Poznańskiego Czerwca, przypisywana dotąd błędnie Antoniemu Czubińskiemu, jest autorstwa Lecha Trzeciakowskiego.

218 J. Sandorski, Poznański Czerwiec a prawo.

219 E. Makowski, Poznański Czerwiec - stan badań, pytania i wątpliwości.

220 A. Plenzler, Czerwiec '56 początek czy koniec?, "Głos Wielkopolski” 1994, nr 146, s. 2.

${ }^{221}$ K. Bedyński, Więzienia i więziennictwo w czasie poznańskiego Czerwca 1956.

222 Tegoż, Problematyka więzienna Poznańskiego Czerwca 1956 r., „Przegląd Więziennictwa Polskiego" 1998, nr 18, s. 61-78; zob. polemika K. Pawlak, Jeszcze o problematyce więziennej Poznańskiego Czerwca 1956 roku, „Przegląd Więziennictwa Polskiego” 1999, nr 22/23, s. 159-162.

223 Zorganizowana przez: Urząd Miasta Poznania, Instytut Pamięci Narodowej, Uniwersytet im. Adama Mickiewicza w Poznaniu, Wyższą Szkoła Nauk Humanistycznych i Dziennikarstwa w Poznaniu, Instytut Zachodni w Poznaniu. 
w Poznaniu. W 2016 r., w związku z sześćdziesiątą rocznicą Poznańskiego Czerwca 1956 r. zostały zorganizowane dwie konferencje i panel dyskusyjny. 10 czerwca 2016 r. odbyła się w Instytucie Historii UAM w Poznaniu ${ }^{224}$ konferencja pt. Poznański Czerwiec 1956 roku w kulturze masowej w latach 1956-2015. 24 czerwca w Bibliotece Raczyńskich w Poznaniu odbył się panel dyskusyjny Wydarzenia 1956 roku w Europie Środkowo-Wschodniej. Próba spojrzenia transnarodowego zorganizowany przez Oddział Instytutu Pamięci Narodowej w Poznaniu i Instytut Filozofii UAM. W ramach I Międzynarodowego Kongresu Bezpieczeństwa w Toruniu, zorganizowanego przez Wyższą Szkołę Bezpieczeństwa z siedzibą w Poznaniu w dniach 7-9 grudnia 2016 r., osobny panel - pod kierunkiem Łukasza Jastrząba - został poświęcony wydarzeniom 1956 r. z perspektywy historyków, dziennikarzy, socjologów, kulturoznawców, politologów, literaturoznawców, historyków sztuki, wojskowych. Warto odnotować również drobniejsze przedsięwzięcia, debaty, jak np. w redakcji „Głosu Wielkopolskiego” w 1993 r. ${ }^{225}$, czy dyskusję z kombatantami w Instytucie Historii UAM, zorganizowaną przez Wiesława Olszewskiego 6 lutego 2006 r. ${ }^{226}$

Powyższy tekst był próbą przekazania w miarę wyczerpującej wiedzy na temat Poznańskiego Czerwca w historiografii i kulturze. Niewątpliwie wymaga dokładnego rozpoznania i opisania symbolika Czerwca w materiałach rozproszonych, takich jak: plakietki, proporczyki, pocztówki, znaczki itp. Przydałaby się również nowa bibliografia Poznańskiego Czerwca, pogłębione studia filmoznawcze czy w końcu monografia.

224 Organizatorzy: Zakład Historii Najnowszej Polski IH UAM, Pracowania Historii Wizualnej, Sekcja Historii Polski XX wieku, Sekcja Historii Wizualnej i Filmowej Studenckiego Koła Naukowego Historyków im. Gerarda Labudy przy IH UAM.

225 Jesteśmy strażnikami tej wielkiej prawdy, "Głos Wielkopolski” 1993, nr 146, s. 3. Patrz też Obiady w "Głosie Wielkopolskim", notował i zredagował W. Braniecki, „Głos Wielkopolski”, Poznań 1993.

226 P. Bojarski, Teczka kombatanta, "Gazeta Wyborcza” nr 32(5040) z 7 lutego 2006 r., dodatek „Poznań”, s. 2; S. Kmiecik, Spór nieobecnych, „Głos Wielkopolski” nr 32(18823) z 7 lutego 2006 r., s. 5. 
Łukasz Jastrząb

\title{
Poznański Czerwiec 1956 r. w kulturze i historiografii
}

\section{Streszczenie}

Tekst jest próbą uporządkowania wiedzy na temat obecności Poznańskiego Czerwca w szeroko rozumianej kulturze i historiografii. Opisuje wątki dotyczące wydarzenia w prozie, poezji, filmie fabularnym i dokumentalnym, omawia literaturę przedmiotu i konferencje tematyczne. W artykule jest również informacja o Muzeum Poznańskiego Czerwca jak i wydarzeniach kulturalnych, teatralnych i multimedialnych.

\section{The Poznań June of 1956 in culture and historiography}

\begin{abstract}
The text is an attempt to organize knowledge about the inclusion of the Poznan protests of June 1956 in the broadly understood culture and historiography. It describes the presence of the event in literature, poetry, fictional and documentary films, but also discusses publications and conferences concerning the protests. The article also provides information on the Museum of the Poznań June, as well as on events related to culture, theater and multimedia.
\end{abstract}

